\title{
Food-web changes in the Adriatic Sea over the last three decades
}

\author{
Marta Coll $^{1,2, *}$, Alberto Santojanni ${ }^{3}$, Isabel Palomera ${ }^{1}$, Enrico Arneri ${ }^{3}$ \\ ${ }^{1}$ Institute of Marine Science (ICM-CSIC), Passeig Marítim de la Barceloneta, 37-49, 08002 Barcelona, Spain \\ ${ }^{2}$ Dalhousie University, Department of Biology, Oxford Street, Halifax, Nova Scotia B3H 4J1, Canada \\ ${ }^{3}$ Istituto di Scienze Marine (CNR), Sede di Ancona, Largo Fiera della pesca 2, 60125 Ancona, Italy
}

\begin{abstract}
We used a process-oriented model (Ecosim) to characterize changes in marine resources in the north-central (NC) Adriatic Sea (Mediterranean) from 1975 to 2002, and to explore the extent to which these changes were driven by trophic interactions, environment and fishing. Fishing efforts and fishing mortalities were used to drive the ecosystem model, and available biomass and catch data were compared to the model predictions. We calibrated and assessed the fit of the model using the sum of the squared deviations of the observed and predicted biomass values. Trophodynamic indicators were then calculated and used to analyse changes to the ecosystem. Trophic interactions, fishing, and environmental conditions were important driving factors of the ecosystem. Predictions from the model adequately matched observed biomass and catch data for each year. Observed trends and predicted data for biomasses decreased with time for several species, including Norway lobster, hake, red mullets, flatfish, and anchovy. The environmental functions resulting from the fitting procedure predicted that primary production and nutrients increased beyond the baseline from 1975 level, and then showed a decrease. They were negatively correlated with mean sea surface temperature and positively correlated with the Mediterranean Oscillation Index. Our results suggested that the NC Adriatic ecosystem became more degraded over time due to expanding fishing effort, bottom-up effects, and climatic anomalies. Possible mechanisms involved are discussed. Comparing our findings with descriptions of the south Catalan Sea ecosystem showed certain similarities between these 2 Mediterranean ecosystems and revealed unique features of the Adriatic Sea.
\end{abstract}

KEY WORDS: Food-web modelling · Ecopath with Ecosim · Fishing impacts $\cdot$ Environmental factors Ecosystem indicators $\cdot$ Adriatic Sea $\cdot$ Mediterranean

Resale or republication not permitted without written consent of the publisher

\section{INTRODUCTION}

The north-central (NC) region of the Adriatic Sea constitutes the widest continental shelf in the Mediterranean Sea (Pinardi et al. 2006) and features a diversity of environmental habitats. This environmental diversity is reflected by the great marine biodiversity (Ott 1992), and fishing from the area is of great economic interest to Italy and other European countries (Bombace 1992).

Notable changes in abundance and biomass of marine organisms have been described for the Adriatic Sea, due primarily to environmental changes and the impact of fishing. On the one hand, fishing catch increased from the mid-1970s to the mid-1980s due to an overall increase in catch, especially of small pelagic fish. This increase was followed by fluctuations in annual catch. Since the late 1980s, catch progressively declined primarily due to a decrease in the biomass of small pelagic fish, particularly anchovy Engraulis encrasicolus, sardine Sardina pilchardus (Cingolani et al. 1996, Azzali et al. 2002, Santojanni et al. 2003, 2005), and demersal fish (Coll et al. 2007). Several demersal target species are known to be overexploited (e.g. Jukić-Peladić et al. 2001, Vrgoć et al. 2004, Bombace \& Grati 2007), and a large amount of discards is produced (Wieczorek et al. 1999, Pranovi et al. 2001, Tudela 2004). 
On the other hand, environmental factors notably affect primary and secondary production in the Adriatic Sea (e.g. Agostini \& Bakun 2002, Santojanni et al. 2006a, Grbec et al. 2002, 2008, Marasović et al. 2005). Runoff from the Po River influences the productivity of the marine ecosystem and has been linked to anchovy landings during its spawning season in the northern areas (Revelante \& Gilmartin 1977, Santojanni et al. 2006a). Anchovy spawning is greatest along the western Adriatic basin where primary production is highest. Water circulation and primary productivity may indeed regulate the intensity of anchovy spawning (Regner 1996). Po river runoff and sardine recruitment are also weakly correlated (Santojanni et al. 2006b). In the southeastern Adriatic Sea, northern hemisphere climate fluctuations were related to the amount of small pelagic fish landings. The advection of Levantine Intermediate Water (LIW), which sinks to intermediate depths of 300 to $500 \mathrm{~m}$ due to its salinity and density (Artegiani et al. 1997), was correlated with increased production and fish abundance (Marasović et al. 1995, Grbec et al. 2002). The progressive increase in water temperature of the Adriatic Sea (Smith \& Reynolds 2004) may cause increasing abundance of certain warm-water species and the disappearance of less heat-tolerant species (Dulčić et al. 1999). These environmental changes may intensely influence fish species dynamics (Grbec et al. 2002, 2007, 2008).

Target and non-target species show complex interactions, and environmental factors can intensely influence ecosystem dynamics. Fishing can cause direct and indirect ecological impacts that may be synergistic to oceanographic modifications and anthropogenic or natural disturbances (Cury et al. 2003). To advance our understanding of the NC Adriatic Sea ecosystem, a mass-balance model was recently developed (Coll et al. 2007). It included the best available data, and represented the marine food web of the mid-1990s, after the collapse of the anchovy stock and the decrease of other small pelagic fish species in the area (Cingolani et al. 1996, Azzali et al. 2002, Santojanni et al. 2003, 2005).

This ecosystem model established a baseline for the NC Adriatic Sea, from which temporal simulations may be developed using dynamic modelling tools to explore the ecological roles of different factors. The ecosystem modelling tool Ecopath with Ecosim (EwE) (Christensen \& Walters 2004) has led to substantial progress in incorporating temporal dynamics into ecosystem analyses while accounting for trophic interactions, exploitation, and environmental conditions (Walters et al. 1997). The temporal dynamic module Ecosim allows researchers to calibrate and fit models to available time series data while exploring the contribution of different ecosystem drivers to marine resource dynamics (e.g. Heymans 2004, Shannon et al.
2004, Araújo et al. 2006, Guénette et al. 2006). The ability to calibrate and fit ecological models increases confidence in model predictions, and can be used to analyze ecosystem dynamics.

To explore the drivers of changes in Adriatic marine resources, we extended the available mass-balance model of the NC Adriatic Sea to reflect changes over time. We calibrated and fitted this time-dynamic model with the time series data from 1975 to 2002. Trophodynamic indicators were used to analyze temporal dynamics of the food web. The 3 major aims of this study were (1) to explore the dynamics of marine resources in the NC Adriatic Sea from 1975 to 2002 considering fishing and environmental factors as primary external drivers, (2) to quantify the structural and functional changes of the ecosystem using indicators obtained from modelling simulations, and (3) to formulate generalities by comparing these results with changes described for the northwest Mediterranean Sea (Coll et al. 2008a). This comparison was performed with similarly derived results from the south Catalan Sea. The Mediterranean Sea, a large marine ecosystem, is highly heterogenic. While some similarities occur, regional differences are important (Agostini \& Bakun 2002, Bosc et al. 2004). The Adriatic Sea differs greatly from the northwestern Mediterranean Sea, including different geographic and oceanographic patterns (e.g. showing a wider continental platform with shallower waters and lower water exchange with other Mediterranean water bodies), environmental conditions (e.g. higher temperatures and salinity), and ecological features (e.g. higher primary and secondary production). These differences also translate into differences in fishing activity (Papacostantinou \& Farrugio 2000, Pinardi et al. 2006). Comparison of the NC Adriatic with the Catalan Sea allowed us to highlight similarities and differences in marine resource trends in these 2 subsystems of the Mediterranean basin during the last 3 decades. This constitutes the first comparison of 2 trophodynamic models calibrated and fitted to time series data in this basin and allows an in-depth analysis of biological changes of these ecosystems facing anthropogenic pressures and widespread climatic events.

\section{MATERIALS AND METHODS}

Area of study. We chose the NC Adriatic Sea as a study area because it has largely consistent ecological and fishing characteristics (Bombace 1992). We considered a depth range between 10 and $200 \mathrm{~m}$ (mean depth $75 \mathrm{~m}$ ) and covered approximately $55500 \mathrm{~km}^{2}$ (Fig. 1). The area within $3 \mathrm{n}$ miles from the coast and less than $10 \mathrm{~m}$ depth, where the artisanal fleets mainly 


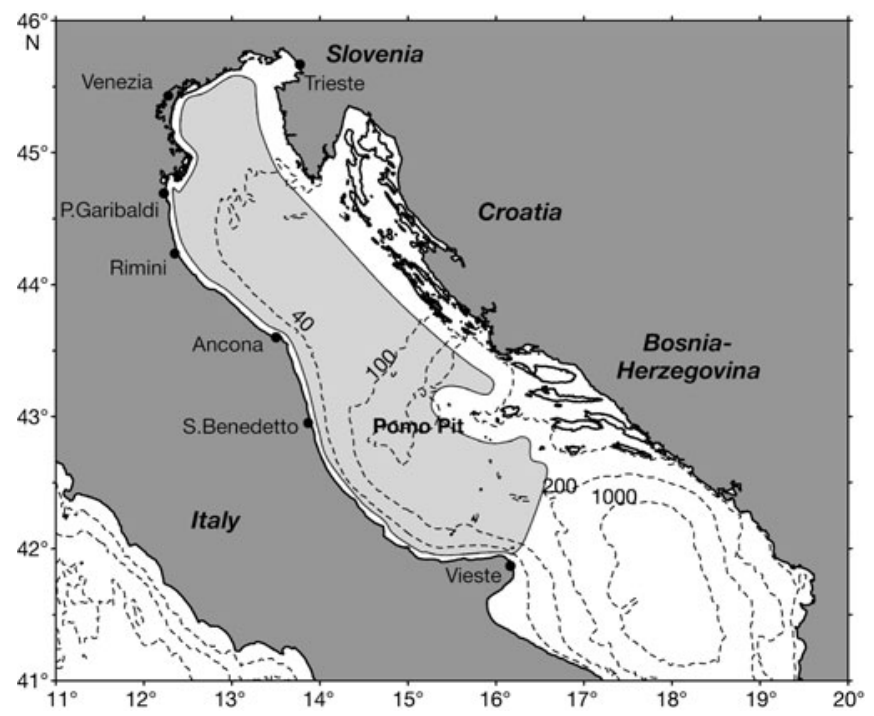

Fig. 1. The north-central (NC) Adriatic Sea. Study area highlighted in light grey, land in dark grey

operate and trawling is banned, were excluded from the western study area. The area within $12 \mathrm{~nm}$ from the coast, i.e. the Croatian territorial waters with its rocky archipelagos, was excluded from the eastern study area. Due to river runoff and oceanographic conditions, the NC Adriatic Sea exhibits 2 gradients of nutrient content and production (north to south and west to east) (Zavatarelli et al. 1998). Water circulation in this region is generally baroclinic and 3 primary water bodies have been identified in the Adriatic Sea (Artegiani et al. 1997): surface water, deep water, and modified Levantine Intermediate Water. Several studies inform on distribution and abundance of marine fauna and flora of the NC Adriatic Sea (e.g. Riedl 1986, Županović \& Jardas 1989, Groombridge 1990, Zotier et al. 1999, Jukić-Peladić et al. 2001, Bearzi et al. 2004).

Mass balance and temporal dynamic modelling. Following the procedure described in Coll et al. (2008a), a mass-balance trophic model representing the annual conditions in NC Adriatic Sea during the last half of the 1990s (Coll et al. 2007) was extended back to 1975, incorporating historical information (Scaccini 1965, Arneri 1981, Piccinetti \& Piccinetti Manfrin 1984, Županović \& Jardas 1989, Šimunović 1997, Azzali et al. 2002, Cingolani et al. 2002a, Santojanni et al. 2003) and biological data from the Istituto di Scienze Marine-Sede di Ancona. Modified input-biomass values $\left(B_{i}\right)$, several production/ biomass $(P / B)_{i}$ and consumption/biomass ratios $(Q / B)_{i}$, as well as catch $\left(Y_{i}\right)$, and output parameters of the model from 1975 are shown in Table 1. Initial diet information was taken from the model for the 1990s, based on scientific literature (Coll et al. 2007). This new ecological model provided the initial conditions used in performing the trophodynamic simulation described below.
The 1975 model was composed of 40 functional groups (defined as species, groups of species, or developmental stages of species), representing the main trophic components of the ecosystem, from primary producers to top predators. These functional groups included natural detritus and discards from fishing activities. The most common fishing activities performed by regional operating fleets were also included in the analysis (bottom and beam trawls, mid-water trawls, purse seines and tuna fishing fleets). Migratory patterns of large pelagic fish and seabirds were considered by modelling a proportion of the diet composition of these groups as imports to the ecosystem, and by describing a migratory flux of production in the area (Coll et al. 2007).

Enough data was available only for hake to describe 2 age groups within the model: namely, the vulnerable 'hake (1)' group of fish $<40 \mathrm{~cm}$ in length mainly caught by trawling, and non-vulnerable 'hake (2)' group of fish $>40 \mathrm{~cm}$, which is mainly not fished. Production/biomass ratio $(P / B)_{i}$ and diet composition were recorded for both groups, and biomass $B_{i}$ and consumption/biomass ratio $(Q / B)_{i}$ were recorded only for 'hake (1)' (Abella et al. 1997, Caddy \& Abella 1999, Vrgoć et al. 2004). To ensure consistency between ontogenetic groups, multiple stanza representation was used in the modelling procedure (Christensen \& Walters 2004). Moreover, several novel ecological parameters from previously published models were introduced to our hake analysis, namely the annual value from the von Bertalanffy growth function $(\mathrm{k}=0.16)$ and the ratio of weight at maturity to the weight at infinity $\left(W_{\text {mat }} / W_{\text {inf }}=0.055 ;\right.$ Vrgoć et al. 2004).

The Ecopath and Ecosim approach (EwE) version 5.1 (Christensen \& Walters 2004) was used to ensure energy balance of the new model. The model equation is as follows:

$$
P_{i}=\sum_{j} B_{j} M 2_{i j}+Y_{i}+E_{i}+B A_{i}+P_{i}\left(1-E E_{i}\right)
$$

EwE divides the production $(P)$ of the ith component, or functional group $(i)$, into predation mortality $\left(M 2_{i j}\right)$, caused by the biomass of the other predators $\left(B_{j}\right)$; exports from the system from fishing catches $\left(Y_{i}\right)$, and emigration $\left(E_{i}\right)$; biomass accumulation in the ecosystem $\left(B A_{i}\right)$; and other mortality $\left(1-E E_{i}\right)$, where $E E_{i}$ is the ecotrophic efficiency of the group within the system, or the proportion of the production $P_{i}$ that is exported out of the ecosystem (i.e. by fishing activity) or consumed by predators.

Eq. (1) can be expressed as:

$B(P / B)_{i}=$

$\sum_{j} B_{j}(Q / B)_{j} D C_{i j}+Y_{i}+E_{i}+B A_{j}+B_{i}(P / B)_{i}\left(1-E E_{i}\right)$ 
Table 1. Input (regular) and output (italic) parameters for the ecosystem components used in the north-central (NC) Adriatic Sea model (1975). B: biomass $\left(\mathrm{km}^{-2}\right), P / B$ : production/biomass ratio $\left(\mathrm{yr}^{-1}\right), Q / B$ : consumption/biomass ratio $\left(\mathrm{yr}^{-1}\right)$, EE: ecotrophic efficiency, U/Q: unassimilated food, landings and discards expressed in $\mathrm{t} \mathrm{km}^{-2} \mathrm{yr}^{-1}$, TL: trophic level

\begin{tabular}{|c|c|c|c|c|c|c|c|c|c|}
\hline \multicolumn{2}{|c|}{$\begin{array}{l}\text { Functional } \\
\text { group }\end{array}$} & \multirow{2}{*}{$\begin{array}{c}B \\
16.658\end{array}$} & \multirow{2}{*}{$\begin{array}{c}P / B \\
69.07\end{array}$} & \multirow[t]{2}{*}{$Q / B$} & \multirow{2}{*}{$\begin{array}{c}E E \\
0.34\end{array}$} & \multirow[t]{2}{*}{$U / Q$} & \multirow[t]{2}{*}{ Landings } & \multirow[t]{2}{*}{ Discards } & \multirow{2}{*}{$\begin{array}{c}\text { TL } \\
1.00\end{array}$} \\
\hline 1 & Phytoplankton & & & & & & & & \\
\hline 2 & Micro- and mesozooplankton & 9.512 & 24.00 & 61.00 & 0.88 & 0.40 & & & 2.05 \\
\hline 3 & Macrozooplankton & 0.545 & 21.28 & 53.14 & 1.00 & 0.16 & & & 3.03 \\
\hline 4 & Jellyfish & 2.172 & 14.60 & 50.48 & 0.17 & 0.10 & & & 2.66 \\
\hline 5 & Suprabenthos & 1.010 & 8.40 & 54.36 & 1.00 & 0.27 & & & 2.11 \\
\hline 6 & Polychaetes & 9.984 & 1.90 & 11.53 & 0.11 & 0.58 & & & 2.00 \\
\hline 7 & Commercial bivalves and gastropods & 0.893 & 1.06 & 3.13 & 0.01 & 0.43 & 0.011 & & 2.00 \\
\hline 8 & Benthic invertebrates & 79.763 & 1.06 & 3.13 & 0.05 & 0.43 & & 0.009 & 2.00 \\
\hline 9 & Shrimps & 0.338 & 3.21 & 7.20 & 0.95 & 0.20 & 0.025 & 0.009 & 3.03 \\
\hline 10 & Norway lobster & 0.037 & 1.25 & 4.56 & 0.98 & 0.20 & 0.028 & & 3.69 \\
\hline 11 & Mantis shrimp & 0.049 & 1.50 & 4.56 & 0.67 & 0.20 & 0.031 & & 3.26 \\
\hline 12 & Crabs & 0.542 & 2.44 & 5.00 & 0.99 & 0.20 & 0.006 & 0.004 & 2.96 \\
\hline 13 & Benthic cephalopods & 0.153 & 2.96 & 6.00 & 0.99 & 0.13 & 0.180 & & 3.25 \\
\hline 14 & Benthopelagic cephalopods & 0.060 & 3.11 & 26.47 & 0.61 & 0.35 & 0.080 & & 4.13 \\
\hline 15 & Hake (1) & 0.200 & 1.00 & 4.34 & 0.99 & 0.20 & 0.181 & 0.017 & 3.98 \\
\hline 16 & Hake (2) & 0.23 & 0.50 & 1.90 & 0.00 & 0.20 & & & 4.10 \\
\hline 17 & Other gadiformes & 0.243 & 1.59 & 4.38 & 0.34 & 0.20 & 0.075 & 0.042 & 3.34 \\
\hline 18 & Red mullets & 0.061 & 1.90 & 8.02 & 0.54 & 0.20 & 0.060 & & 3.13 \\
\hline 19 & Conger eel & 0.008 & 1.92 & 6.45 & 0.86 & 0.20 & & 0.0100 & 4.16 \\
\hline 20 & Anglerfish & 0.018 & 1.04 & 4.58 & 0.96 & 0.20 & 0.018 & & 4.49 \\
\hline 21 & Flatfish & 0.070 & 1.43 & 9.83 & 0.99 & 0.20 & 0.090 & & 3.81 \\
\hline 22 & Turbot and brill & 0.037 & 1.43 & 5.34 & 0.95 & 0.20 & 0.019 & & 4.12 \\
\hline 23 & Demersal sharks & 0.055 & 0.63 & 4.48 & 0.99 & 0.20 & 0.034 & & 4.00 \\
\hline 24 & Demersal skates & 0.069 & 1.11 & 7.08 & 0.44 & 0.20 & 0.029 & & 4.12 \\
\hline 25 & Demersal fish $(1)^{\mathrm{a}}$ & 0.285 & 2.40 & 7.68 & 0.99 & 0.20 & 0.274 & 0.069 & 3.29 \\
\hline 26 & Demersal fish $(2)^{a}$ & 0.127 & 2.40 & 5.68 & 0.95 & 0.20 & 0.033 & & 3.62 \\
\hline 27 & Benthopelagic fish ${ }^{\mathrm{a}}$ & 0.658 & 1.07 & 7.99 & 0.95 & 0.30 & 0.039 & & 3.69 \\
\hline 28 & Anchovy & 2.529 & 0.87 & 11.02 & 0.99 & 0.30 & 0.727 & 0.001 & 3.05 \\
\hline 29 & Sardine & 4.518 & 0.75 & 9.19 & 0.83 & 0.30 & 0.767 & 0.004 & 2.97 \\
\hline 30 & Other small pelagic fish & 1.071 & 1.10 & 11.29 & 0.49 & 0.30 & 0.044 & 0.003 & 3.23 \\
\hline 31 & Horse mackerel & 1.346 & 0.99 & 7.57 & 0.29 & 0.20 & 0.042 & 0.021 & 3.46 \\
\hline 32 & Mackerel & 0.638 & 0.99 & 6.09 & 0.52 & 0.20 & 0.009 & 0.001 & 3.31 \\
\hline 33 & Atlantic bonito & 0.300 & 0.39 & 4.54 & 0.00 & 0.20 & 0.002 & & 4.04 \\
\hline 34 & Large pelagic fish & 0.117 & 0.37 & 1.99 & 0.00 & 0.20 & 0.006 & & 4.23 \\
\hline 35 & Dolphins & 0.012 & 0.08 & 11.01 & 0.23 & 0.20 & & 0.0002 & 4.27 \\
\hline 36 & Loggerhead turtle & 0.032 & 0.17 & 2.54 & 0.76 & 0.20 & & 0.004 & 3.01 \\
\hline 37 & Sea birds & 0.001 & 4.61 & 69.34 & 0.22 & 0.20 & & 0.001 & 4.12 \\
\hline 38 & Discards & 0.733 & & & 0.37 & & & & 1.00 \\
\hline 39 & By-catch & 0.004 & & & 0.00 & & & & 1.00 \\
\hline 40 & Detritus & 200.0 & & & 0.45 & & & & 1.00 \\
\hline
\end{tabular}

where $(P / B)_{i}$ indicates the production of $i$ per unit of biomass, and is equivalent to total mortality $(Z)$ under steady-state conditions (Allen 1971); $(Q / B)_{i}$ is the consumption of $i$ per unit of biomass; and $D C_{i j}$ indicates the proportion of $i$ that is in the diet of predator $j$ in terms of volume or weight. EwE parameterizes the model by describing a system of linear equations for all the functional groups in the model, where for each equation at least 3 of the basic parameters $B_{i},(P / B)_{i}$, $(Q / B)_{i}$ or $E E_{i}$ must to be known for each group $i$. The unassimilated food rate or the fraction of the food consumption not assimilated $(U / Q)$ and the fate of detritus are also required parameters in this model. The energy balance within each group is guaranteed when consumption by group $i$ equals production by $i$, respiration by $i$, and food unassimilated by $i$.

The NC Adriatic Sea ecosystem model extending to 1975 was then used to analyze the main temporal dynamics of the food web. The model was calibrated and fitted for the period 1975 to 2002 using the temporal dynamic module Ecosim (Walters et al. 1997). Ecosim uses a system of time-dependent differential equations from the baseline mass-balance model, where the biomass growth rate is expressed as:

$$
\mathrm{d} B_{i} / \mathrm{d} t=(P / Q)_{i} \sum Q_{j i}-\sum Q_{i j}+I_{i}-\left(M_{i}+F_{i}+e_{i}\right) B_{i}
$$


where $(P / Q)_{i}$ is the gross efficiency; $M_{i}$ is the natural non-predation mortality rate; $F_{i}$ is the fishing mortality rate; $e_{i}$ is the emigration rate; $I_{i}$ is the immigration rate; and $B_{i}$ is the biomass of the functional group $i$. Calculations of consumption rates $\left(Q_{i j}\right)$ are based on the 'foraging arena' theory, where the biomass of prey $i$ is divided into vulnerable and a non-vulnerable fractions (Walters \& Juanes 1993). Vulnerabilities $\left(v_{i j}\right)$ express the maximum increase in predation mortality under conditions of high predator/prey abundance. Low vulnerability (close to 1) indicates that an increase in predator biomass will not result in any substantial increase in predation mortality, and can be related with bottom-up effects. High vulnerability indicates that if the predator biomass is doubled, it will result in an approximate doubling of the predation mortality for a given prey species, and can be related with top-down effects (Christensen et al. 2005). A limit to consumption rate can be introduced by modifying default behavioural parameters (e.g. the effective search rate of species, feeding time, and handling time), or by including seasonal or long term forcing effects and mediation functions (Christensen et al. 2005). By calculating the consumption of each functional group, Ecosim allows us to consider different mechanisms of flow control, the ecological behaviour of organisms, and forcing elements such as environmental variables. A review of EwE approach, capabilities and limitations can be found in Christensen \& Walters (2004), Christensen et al. (2005) and Plagányi (2007).

Calibration procedure and simulations. The following procedure modified from Shannon et al. (2004) and Araújo et al. (2006), and similar to the one followed in Coll et al. (2008a), was applied to calibrate the model of the NC Adriatic Sea (Table 2) for the period 1975 to 2002. A reduction in the sum of squared deviations (SS) of observed log biomass from predicted log biomass values was used as a metric in assessing the fit of the model (Christensen et al. 2005):

(1) Input of data: data was read into EwE from CSV files. Fishing effort and mortality data were used to drive the model from 1975 to 2002. To assess the fit of the model, absolute and relative biomass data were compared to predicted model results, and the baseline goodness-of-fit of the model was calculated ( $\mathrm{SSi}, \mathrm{i}=$ initial). Catch data were utilized only for comparison purposes due to the incomplete nature of the dataset.

(2) Search for vulnerabilities: the Ecosim module 'fit to time-series' was used to identify prey-predator interactions that were most sensitive to changes in $v_{i j}$, and these interactions were refined to improve the fit of the model. The 20 most sensitive $v_{i j}$ values were recorded, and a vulnerability search was performed to estimate the $v_{i j}$ values that would minimize the SSi.

(3) Search for environmental anomaly functions (EF): by implementing a non-parametric routine incorpo-

Table 2. Time series data used to simulate the temporal dynamics in the north-central (NC) Adriatic Sea (1975 to 2002) regarding data used to drive and to fit the model, and to compare results. ISTAT, IREPA: governmental statistical institutes, ISMAR-CNR: Instituto di Science Marine-Sede di Aucona, VPA: virtual population analysis, ICCAT: International Commission for the Conservation of Atlantic Tunas

\begin{tabular}{|c|c|c|c|c|c|}
\hline Functional group & Time series of data & Observations & $\begin{array}{c}\text { To drive } \\
\text { model }\end{array}$ & $\begin{array}{l}\text { To fit } \\
\text { model }\end{array}$ & $\begin{array}{l}\text { To compare } \\
\text { results }\end{array}$ \\
\hline Norway lobster & $\begin{array}{l}\text { Total catches ( } \mathrm{km}^{-2} \mathrm{yr}^{-1} \text { ) } 1975 \text { to } 2000 \\
\text { (corrected for reporting errors) } \\
\text { Fishing effort by fleet } 1975 \text { to } 2002 \\
\text { CPUEs } 1982 \text { to } 2002\end{array}$ & $\begin{array}{l}\text { ISTAT, IREPA, ISMAR-CNR } \\
\text { ISTAT, IREPA } \\
\text { Scientific surveys (Grund data) }\end{array}$ & $\mathbf{x}$ & $\mathbf{x}$ & $\mathbf{x}$ \\
\hline $\begin{array}{l}\text { Hake(1), mullets, } \\
\text { anglerfish, conger, } \\
\text { flatfish, demersal } \\
\text { sharks and skates }\end{array}$ & $\begin{array}{l}\text { Total catches ( } \mathrm{km}^{-2} \mathrm{yr}^{-1} \text { ) } 1975 \text { to } 2000 \\
\text { (corrected for reporting errors) } \\
\text { Fishing effort by fleet } 1975 \text { to } 2002 \\
\text { CPUEs from } 1982 \text { to } 2002\end{array}$ & $\begin{array}{l}\text { ISTAT, IREPA, ISMAR-CNR } \\
\text { ISTAT, IREPA } \\
\text { Scientific surveys (GRUND data) }\end{array}$ & $\mathbf{x}$ & $\mathbf{x}$ & $\mathbf{x}$ \\
\hline Anchovy & $\begin{array}{l}\left.\text { Total catches (t km-2 } \mathrm{yr}^{-1}\right) 1976 \text { to } 2002 \\
\text { (corrected for reporting errors) } \\
\text { Absolute biomass }\left(\mathrm{t} \mathrm{km}^{-2} \text { ) } 1976 \text { to } 2002\right. \\
\text { Fishing effort of purse seine and } \\
\text { mid-water trawling } 1975 \text { to } 2002\end{array}$ & $\begin{array}{l}\text { ISTAT, IREPA, ISMAR-CNR } \\
\text { Standardized from VPA }\end{array}$ & $\mathbf{x}$ & $\mathbf{x}$ & $\mathbf{x}$ \\
\hline Sardine & $\begin{array}{l}\left.\text { Total catches ( } \mathrm{km}^{-2} \mathrm{yr}^{-1}\right) 1975 \text { to } 2002 \\
\text { (corrected for reporting errors) } \\
\text { Absolute biomass (t km} \text { k }^{-2} \text { ) } 1975 \text { to } 2002 \\
\text { Fishing effort of purse seine and } \\
\text { mid-water trawling from } 1975 \text { to } 2002\end{array}$ & $\begin{array}{l}\text { ISTAT, IREPA, ISMAR-CNR } \\
\text { Standardized from VPA }\end{array}$ & $\mathbf{x}$ & $\mathbf{x}$ & $\mathbf{x}$ \\
\hline Large pelagic fish & $\begin{array}{l}\text { Catches }\left(\mathrm{t} \mathrm{km}^{-2} \mathrm{yr}^{-1}\right) \text { from the } \\
\text { Mediterranean Sea } 1980 \text { to } 2002 \\
\text { Total biomasses }\left(\mathrm{t} \mathrm{km}^{-2}\right) \text { estimated } \\
\text { using VPA for the Mediterranean Sea } \\
\text { Fishing mortality }\end{array}$ & $\begin{array}{l}\text { Biomass and catch data for } \\
\text { Thunnus thynnus from } 1980 \\
\text { and for Xiphias gladius } \\
\text { from } 1985 \text { (ICCAT) }\end{array}$ & $\mathbf{x}$ & $\mathbf{x}$ & $\mathbf{x}$ \\
\hline
\end{tabular}


rated in Ecosim, we performed a search for primary production or nutrient anomalies (Christensen et al. 2005) to continue minimizing the SS. Primary production anomalies impact the initial phytoplankton $P / B$ value by adding annual modifiers every year (e.g. Shannon et al. 2004, Guénette et al. 2006). Nutrient anomalies are linked to potential nutrient limitation of primary production rates (e.g. Piroddi 2008). An estimate of the F statistic (SSreduced/SSbase) was used to assess the anomaly reliability and to test for the probability that the corresponding decrease on SS values were due to chance alone.

(4) Reverse order procedure: procedures 2 and 3 were reversed in order to estimate the productivity pattern and the $v_{i j}$ values. In addition, both the vulnerability and environmental anomaly searches were run together with the $v_{i j}$ values and the productivity patterns calculated accordingly.

(5) Analysis of results: observed and predicted biomass and catch trends were compared to the empirical data. The primary production and nutrient anomalies obtained from the calibration process were correlated with the available environmental data. Trophodynamic indicators were calculated from model results.

During the calibration process, ecological parameters related to species behaviour were set by default (Christensen et al. 2005), with the exception of vulnerabilities $\left(v_{i j}\right)$ and the parameters linking the age stanzas for hake.

Time series data. The available time series data were compiled and used with the temporal dynamic ecosystem model as follows (Table 2):

(1) Absolute biomass and fishing mortality data for anchovy and sardine were obtained from stock assessment analyses conducted in the area by the Istituto di Scienze Marine, Sede di Ancona using Virtual Population Analysis (VPA) (Santojanni et al. 2005, 2006a, last update discussed at the General Fisheries Commission for the Mediterranean meeting, September 2007). We used the fishing mortality to drive the dynamics of anchovy and sardine.

(2) Relative biomass data for various demersal species were obtained through scientific trawl surveys conducted annually between 1982 and 2002 (GRUND surveys: courtesy of Prof. Corrado Piccinetti, Laboratorio di Biologia Marina e Pesca, Fano, Italy). This data was collected from the western Adriatic basin and covered the bathymetry of the Adriatic Sea from 0 to $200 \mathrm{~m}$ depth of the Italian territorial and international waters. GRUND surveys were conducted during autumn using an Italian commercial net (Vrgoć et al. 2004).

(3) Official landings statistics from 1975 to 2000 were obtained from the governmental statistical institutes (ISTAT and IREPA). To partially complement this dataset we incorporated discard information from the re- gion (e.g. Wieczorek et al. 1999, Cingolani et al. 2000, Affronte \& Scaravelli 2001, Santojanni et al. 2005) and partial estimates of illegal, unregulated, or unreported landings (Mattei \& Pellizzato 1996, Santojanni et al. 2005, Cingolani et al. 2002a,b, E. Arneri, C. Froglia \& C. Piccinetti unpubl. data). Catch data were corrected using independent catch surveys collected from the Istituto di Scienze Marine-Sezione di Ancona (Santojanni 2005, 2006a). Catches from artisanal fisheries located on the immediate coastal area and aquaculture were excluded from the analysis.

(4) Nominal fishing effort in bottom trawling (including both beam and bottom trawling), mid-water trawling and purse seining were expressed in units of horsepower (HP) and number of boats (data from ISTAT, IREPA and ISMAR-CNR). We aggregated the data to represent the NC Adriatic fleets. Trawling data were available from 1975 to 1995 through ISTAT and from 1996 to 2002 through IREPA. The 2 datasets did not align perfectly, so we extended the ISTAT series through 2002, extrapolating the general trend of the series. We used 2 different simulation scenarios, (a) assuming that trawling HP was constant from 1995 to 2002 (as the official data series from IREPA suggested), (b) assuming that the HP increased from 1975 to 1995 (Fig. 2). We used these data as a proxy for fishing effort.

(5) Fishing mortality, absolute biomass, and catch data for bluefin tuna and swordfish were obtained from International Commission for the Conservation of Atlantic Tunas (ICCAT) evaluations of the Mediterranean Sea and Atlantic Ocean stocks (ICCAT 2003, 2004). We used the fishing mortality to drive the dynamics of bluefin tuna and swordfish.

(6) Several environmental parameters from 1975 to 2002 were included: (a) sea surface temperature (SST, annual and winter means, Smith \& Reynolds 2004); (b) Po River runoff (annual mean, $\mathrm{m}^{3} \mathrm{~s}^{-1}$, data provided by SINAPSI project, funded by Italian Ministry for research); (c) North Atlantic Oscillation (NAO) Index (www.cru.uea.ac.uk/cru/data/nao.htm), both annual and winter means, (d) Salinity (mean percent values for the layer 50 to $150 \mathrm{~m}$ for the middle Adriatic Sea, Stn CJ009; Gbrec et al. 2007), and (e) Mediterranean Oscillation Index (MOI; Gbrec et al. 2007).

The primary production anomaly and nutrient anomaly functions resulting from the calibration procedure were correlated with these available environmental data. Linear correlations were obtained by analyzing the anomaly function and the available data with Pearson's product moment correlation along with Spearman's rank correlation when the distribution was not normal. A simple analysis based on a multiple linear regression was also implemented to assess whether the anomaly could be predicted through combinations of 

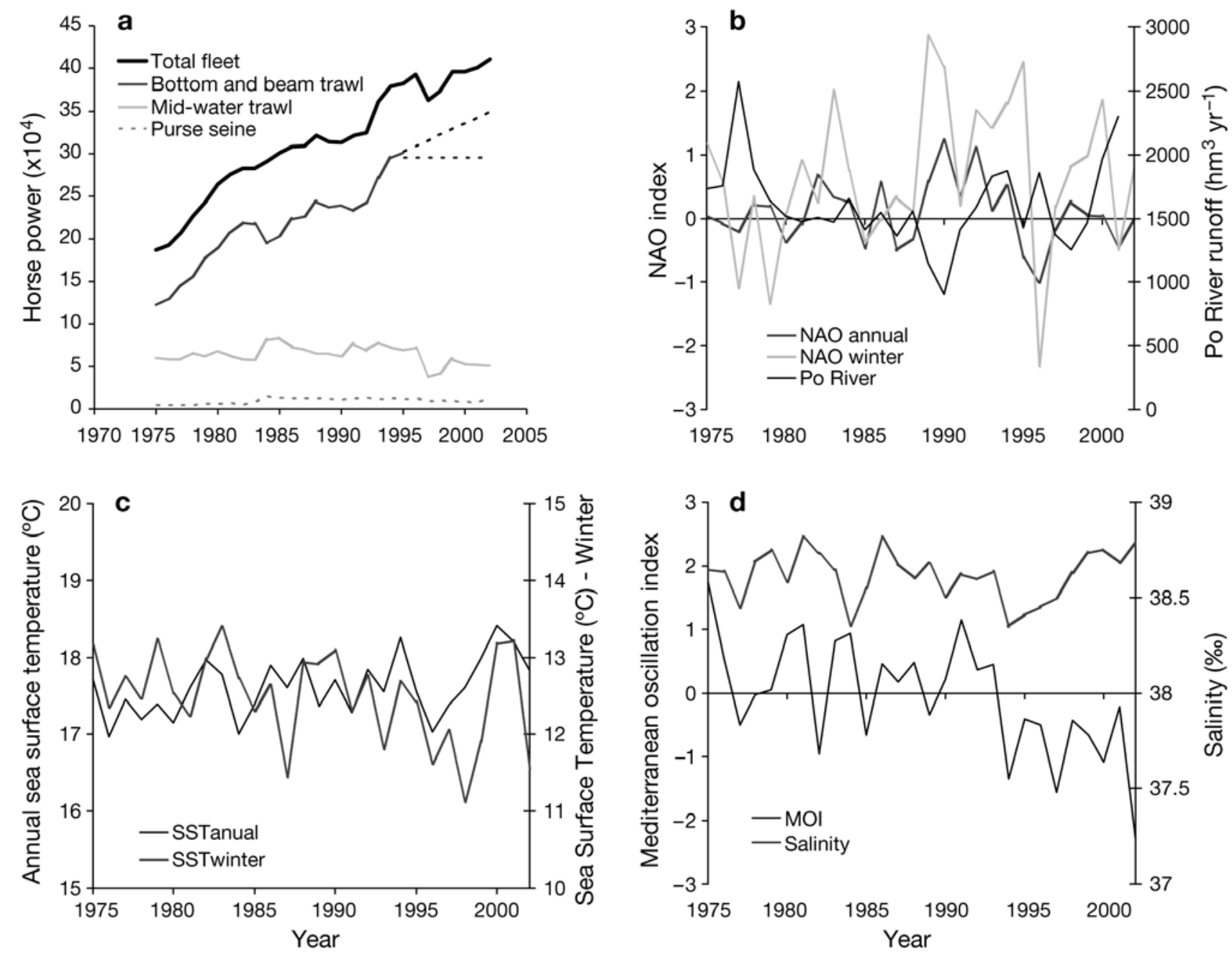

Fig. 2. (a) Nominal fishing efforts from beam and bottom trawling, midwater trawling and purse seine expressed in units of horsepower (HP) (ISTAT and ISMAR-CNR) over time. Trawling data was available from 1975 to 1995 and is extrapolated in 2 ways to simulate an increasing or constant trend from 1995 to 2002. (b) North Atlantic Oscillation (NAO, annual and winter) and Po River runoff (annual mean, $\mathrm{m}^{3} \mathrm{~s}^{-1}$ ). (c) Sea surface temperature (SST, annual mean and winter mean). (d) Mediterranean Oscillation Index (MOI) and salinity (mean values for the depth layer 50 to $150 \mathrm{~m}$ for the central Adriatic Sea)

different types of environmental data. A time series of chlorophyll a concentrations was available through satellite images for the periods 1979 to 1985 (Coastal Zone Color Scanner, CZCS) and 1998 to 2002 (Seaviewing Wide Field-of-view Sensor, SeaWiFS) (N. Bahamon unpubl. data) so it was only included in the correlation analysis.

Ecosystem indicators and analysis. When only partial or anecdotal information was available, or when data was available but not included in the calibration due to low quality, we analyzed the projected time series of catches and biomasses in order to further explore species dynamics. Ecosystem indicators predicted from the model were then examined in order to describe the main structural and functional changes in the ecosystem over time:
(1) The total demersal biomass to pelagic biomass ratio $(D / P)$ was used as an indicator of the processes benefiting demersal or pelagic compartments. The total invertebrate to fish biomass ratio (Inve/Fish) was used as an indicator of changes in the fish community. This ratio is expected to increase with fishing (Rochet \& Trenkel 2003, Cury et al. 2005), while $D / P$ is expected to decrease and is also linked with bottom-up effects (De Leiva et al. 2000).

(2) We calculated a modified version of Kempton's index of biodiversity, the biomass diversity index $Q^{\prime}$. This measures the relative index of biomass diversity, calculated from Kempton's $Q_{75}$ index expressing species diversity (Kempton \& Taylor 1976, Ainsworth \& Pitcher 2006). This index includes species and functional groups with a trophic level (TL) of 3 or higher. It 
increases with growing biomass of high trophic level organisms, and decreases with increased fishing impacts.

(3) The mean trophic level of the community $\left(\mathrm{mTL}_{\mathrm{co}}\right)$ and mean trophic level of the catch $\left(\mathrm{mTL}_{\mathrm{c}}\right)$ were calculated as well. The $\mathrm{mTL}_{\mathrm{c}}$ reflects the fishing strategy in terms of selected food-web components, and is calculated as the weighted average TL of harvested species (Pauly et al. 1998). The $\mathrm{mTL}_{\mathrm{co}}$ reflects the structure of the community and is calculated as the weighted average TL of all species (Rochet \& Trenkel 2003). Both indicators generally decrease with increased fishing impact, due to a reduction in the number of large predators, and a relative increase in lower trophic level organisms. However, they can increase when species with lower or intermediate TLs decrease in the ecosystem, such as small pelagic fish or invertebrates (Coll et al. 2008a).

(4) Total flow to detritus (FD) was calculated as the amount of the total trophic flow that contributed to detritus $\left(\mathrm{t} \mathrm{km}^{-2} \mathrm{yr}^{-1}\right)$. As fishing impact increases, this factor may increase, due to food-web energy path disruption (Walsh 1981, Shannon et al. in press).

(5) The mean transfer efficiency (TE) summarizes the inefficiencies of the food web present at each step of the trophic chain (Lindeman 1942). These inefficiencies may be due to respiration, excretion, egestion and other natural mortalities. The TE was calculated as the ratio of production of a given $\mathrm{TL}$, and the preceding TL (Lalli \& Parsons 1993, Pauly \& Christensen 1995). This ratio may increase with increased fishing impact (Libralato et al. 2005).

(6) The Fishing in Balance index (FIB index) assesses whether catch rates are in balance with ecosystem trophic production due to catch at a given TL is related to assimilation efficiency of the ecosystem. Therefore, you expect higher catches at lower TLs due to this energy transfer. FIB index $=0$ indicates higher production at lower trophic levels, so fishing is in balance. FIB index $>0$ indicates that the fishery has expanded, or that bottom-up effects are occurring, so there is more catch than expected. FIB index $<0$ when discarding occurs and it is not considered in the analysis or when the fishing impact is so high that the ecosystem function is impaired (Christensen 2000).

(7) The loss in production index $(L)$ quantifies the theoretical depletion of secondary production due to fishing in an exploited ecosystem (Libralato et al. 2008, Coll et al. 2008b). This index was proposed as a proxy for characterizing the effects of fishing on the ecosystem, and for estimating the probability that the ecosystem is being fished in a sustainable manner. This index takes into account both the properties of the ecosystem (the primary production and TE) as well as the characteristics of fishing activity $\left(\mathrm{mTL}_{\mathrm{c}}\right.$ and the primary pro- duction required to sustain the fishery, and PPR; Lindeman 1942, Pauly \& Christensen 1995, Pauly et al. 1998). The $L$ index increases with fishing impact.

A trend analysis was performed to assess the significance of model-predicted changes in the time series for biomass, catch data and trophodynamic indicators. Our results were relatively short time series and were frequently characterized by auto-correlation. Thus a simple linear trend model was fit to each of the predicted time series using a generalized least-squares regression framework (as in Coll et al. 2008a), which modelled the temporal correlations in error using a 2 -stage estimation procedure. The significance of the trend (i.e. whether the predicted slope was significantly different from zero) and corresponding p-value and coefficient of variation $\left(\mathrm{R}^{2}\right)$ were recorded. Potential violations of the regression assumptions in terms of non-stationarity and nonlinearity were highlighted. To derive generalities or differences occurring in 2 Mediterranean marine ecosystems during the past 3 decades, results from the trend analysis were compared with those obtained in the south Catalan Sea (Coll et al. 2008a).

\section{RESULTS}

\section{Model setup and calibration}

After the mass-balance model for the NC Adriatic Sea during mid-1990s was modified to represent the ecosystem in 1975, the initial catch estimates for mantis shrimp, squid and mullets were corrected and lowered to better reproduce the population dynamics of these species.

Data from trawling efforts (beam and bottom trawls) was available from 1975 to 1995 from ISTAT, and show an increase in fishing with time. The IREPA data from 1996 to 2002 show a more constant effort. We therefore extrapolated the time series of ISTAT to 2002, with consideration of the general trend. Then, we used the IREPA data by making 2 different simulations of trawling: constant or increasing HP (Fig. 2). The best results from the fitting were obtained when the HP from trawling was modelled to increase from 1995 to 2002, as it did from 1975 to 1995. After appropriately modifying the data, the model was fitted to the data.

\section{Trophic interactions, fishing and the environment as ecosystem drivers}

The goodness-of-fit of the model was notably improved as the variability found in biomass time series when food-web configuration and environmental data 
Table 3. The 20 most sensitive interactions in the NC Adriatic Sea model to changes in the vulnerability parameter. L: low value, Vulnerabilities $\left(v_{i j}\right)$ close to 1 . H: High value, $v_{i j} \gg 1$ )

\begin{tabular}{|c|c|c|c|c|c|c|c|c|c|c|c|}
\hline Prey & 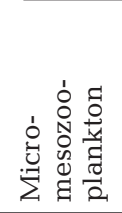 & 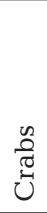 & 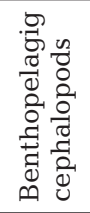 & 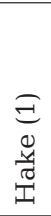 & 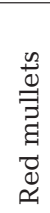 & 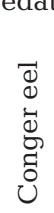 & 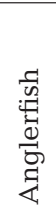 & 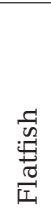 & 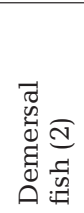 & 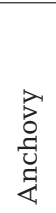 & 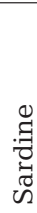 \\
\hline Phytoplankton & $\mathrm{H}$ & & & & & & & & & & \\
\hline Micro-mesozooplankton & & & & & & & & & & $\mathrm{L}$ & $\mathrm{H}$ \\
\hline Suprabenthos & & & & & & & & $\mathrm{H}$ & & & \\
\hline Polychaetes & & $\mathrm{L}$ & & & $\mathrm{L}$ & & & & & & \\
\hline Benthic invertebrates & & & & $\mathrm{L}$ & $\mathrm{H}$ & & & & $\mathrm{L}$ & & \\
\hline Shrimps & & & & & & $\mathrm{L}$ & $\mathrm{L}$ & & & & \\
\hline Crabs & & & & & $\mathrm{L}$ & $\mathrm{L}$ & & $\mathrm{L}$ & & & \\
\hline Other gadiformes & & & & & & & $\mathrm{L}$ & & & & \\
\hline Demersal fish (2) & & & & & & & & $\mathrm{L}$ & & & \\
\hline Benthopelagic fish & & & & & & & $\mathrm{L}$ & $\mathrm{H}$ & & & \\
\hline Anchovy & & & $\mathrm{L}$ & & & $\mathrm{L}$ & & & & & \\
\hline
\end{tabular}

were included in the simulations, driven by both fishing mortality and fishing effort. We observed an $89 \%$ reduction in variability when we searched for vulnerabilities and then for environmental anomaly. A $71 \%$ reduction was obtained when we searched first for the environmental anomaly and then for vulnerabilities. However, the best fit resulted when searching for both parameters at the same time $(91 \%$ reduction of variability). The food-web configuration contributed to a reduction of 83,45 and $84 \%$, while the environmental anomaly did by 6,26 and $7 \%$, when we first considered the vulnerabilities and then the environmental function or when both factors were considered together during the fitting.

Trophic interactions. Changes in vulnerability default values specifying the strength of food-web interactions notably improved the goodness-of-fit of the model. Vulnerabilities $\left(v_{i j}\right)$ resulting from the model are shown in Table 3. Low values ( $v_{i j}$ close to 1$)$ were described for 15 interactions, where crabs, polychaetes, benthic invertebrates, shrimps and anchovy were most important as prey. High values $\left(v_{i j} \gg 1\right)$ were shown by 5 interactions, where flatfish, red mullets, sardine and micro-mesozooplankton were important predators.

Environmental factors. The environmental functions predicted by the model were significant $(p<0.001)$, when we first considered the vulnerabilities and then the environmental function during the fitting, vice versa, or considered both factors simultaneously. The 3 functions were similar, therefore only the value obtained from searching for both vulnerabilities and environmental anomaly is shown, both in terms of phytoplankton biomass and nutrient loading (Fig. 3). Similar results were obtained when we searched for relative phytoplankton production or nutrient loading function anomaly. In both cases, the predicted function increased beyond the baseline from 1975 level, then decreased significantly with time. Both functions showed a positive and significant correlation (Pearson $\mathrm{r}=0.884, \mathrm{p}<0.001)$.

Correlation analysis between the environmental anomalies and environmental data showed a significant negative correlation between phytoplankton anomaly and the mean annual SST (Pearson $\mathrm{r}=-0.394$,

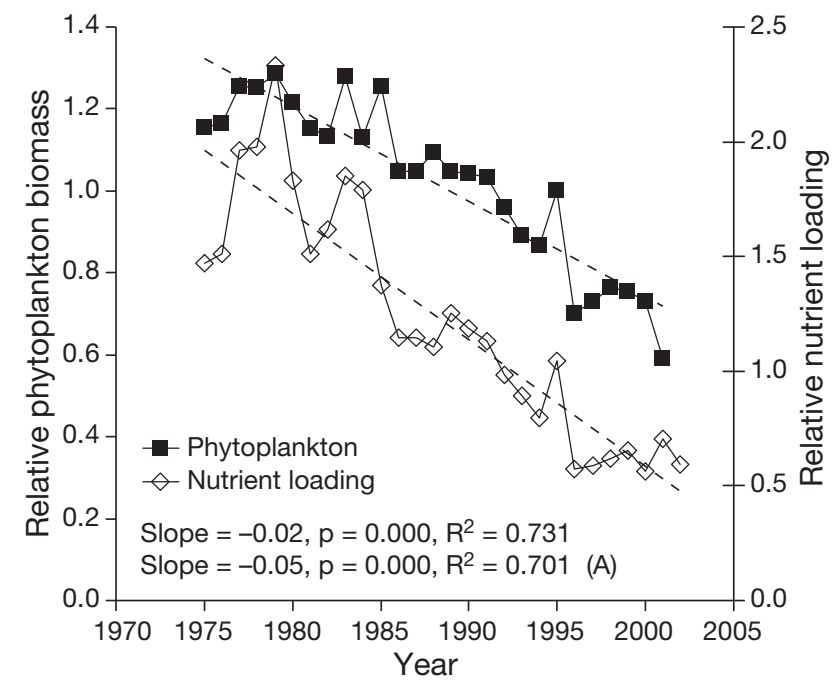

Fig. 3. Environmental anomaly expressed as 'Phytoplankton biomass' and 'Nutrient loading', resulting from the calibration process for the period 1975 to 2002, relative to the baseline 1975 model. The estimated trends (dashed lines) are shown with the value of the slope, the p-value and the coefficient of variation $\left(\mathrm{R}^{2}\right)$ for the regression model (first phytoplankton trend). 'A': data was corrected for autocorrelation and a generalized least squares model was applied for the regression 
$\mathrm{p}=0.038)$ and significant positive correlation with MOI ( $\mathrm{r}=0.416, \mathrm{p}=0.028)$. The nutrient anomaly was negatively correlated with SST $(r=-0.435, \mathrm{p}=0.021)$ as well, and positively correlated with mean winter sea surface temperature, SSTw $(r=0.465, \mathrm{p}=0.013)$ and MOI $(r=0.491, p=0.008)$. Multiple regression models adequately predicted the anomaly functions by integrating the available environmental data, and best regression models included the SST and SSTw as predicting variables $\left(\mathrm{R}^{2}=0.414, \mathrm{p}=0.002\right.$, and $\mathrm{R}^{2}=0.544$, $\mathrm{p}<0.001$, respectively).

Fishing. By looking at the contribution of each parameter to the functional groups fitted to the data, we classified the groups predominantly driven by fishing or environmental anomalies. Fishing mortality and fishing efforts contributed substantially to modelling the time series variability of biomass data for several species: hake (1), anglerfish, conger, flatfish, demersal sharks, demersal skates, anchovy and large pelagic fish. Environmental anomaly was the most important factor in explaining the dynamics of sardine, and to a lesser extent, Norway lobster and red mullets.

\section{Changes in biomass}

The biomass trends estimated by Ecosim when compared with independent observed data showed an overall satisfactory match between predicted and available data (Fig. 4a,e-f,i-j). Exceptions were observed for hake (1) at the beginning of the empirical time series (1982 to 1987), although the rest of biomass data from scientific surveys adequately matched model predictions (Fig. 4b). Poor fitting of the model was also observed for red mullets, where data showed increases in biomass with time, and for conger eel and demersal sharks, for which the data showed indistinct trends (Fig. 4c-d,g). Demersal skates showed higher predicted biomasses than those estimated from scientific independent campaigns, although both time series showed a decreasing trend (Fig. 4h). Large pelagic fish were predicted to have declined from the early 1980s to 2002, while official data available for the Mediterranean Sea show that these species first increased and subsequently decreased during this period (Fig. 4k). Similar results were obtained in searching for a nutrient loading function (which are not shown). The trend analysis highlighted that the predicted time series showed a significant decreasing trend in biomass of several species (Fig. 4a-i,k). Sardine biomass showed an overall increase from 1975 to 1981, followed by a persistent decline (Fig. 4j). The model showed a good fit to the sardine data, but did not reflect the peak in biomass of the mid-1980s. Most of the biomass time series showed strong autocorrelation (Fig. 4), and in the case of flat- fish, the normality assumption was violated. Autocorrelation and normality statistical results are not shown, but are indicated in each figure.

\section{Changes in catch}

The time series of catch trends estimated by Ecosim, when compared with independent data, showed an overall satisfactory match between predictions and observed data (Fig. 5a,c,e-g,i,k). The model overestimated catches for hake (1), conger eel and demersal skates, but showed a long-term trend similar to that observed (Fig. 5b,d,h). Catch trends predicted from the model showed a significant decrease of anglerfish and flatfish over time (Fig. e,i,f), while a non-significant increase was predicted for large pelagic fish (Fig. 5k). An increase and posterior decrease in catches were predicted for Norway lobster, red mullets, demersal sharks, anchovy, sardine and large pelagic fish (Fig. 5a,c,g,i,k). Strong autocorrelations were observed in the predicted catch time series. Total catch predicted for 1975 through 2002 notably matched with time series data available for the NC Adriatic Sea during the same period (Fig. 6).

\section{Ecosystem indicators}

The predicted biomass trends of other functional groups for which no empirical or high-quality data was available showed clearly decreasing trends for hake (2) (Fig. 7d). Jellyfish, benthopelagic fish, other small pelagic fish and horse mackerel showed large fluctuations and a general decrease with time (Fig. 7a,c,f,g). Shrimps, gadiformes and seabirds first showed an increase followed by a decrease in biomass (Fig. 7b,e,i), and mackerel showed only minor changes with time. These trends were matched with independent data in the case of benthopelagic fish, other small pelagic fish, and horse mackerel.

A modified version of Kempton's index of biodiversity and the $\mathrm{mTL}_{\mathrm{co}}$ (excluding $\mathrm{TL}=1$ ) showed a significantly decreasing trend through time (Fig. 8a,d). The TTL $_{\text {со }}$ (including all trophic levels), the mean trophic level of the catch, and the flow to detritus decreased as well, but these were not significant (Fig. 8e-g). The demersal/ pelagic biomass ratio showed an increase and then a decrease with time, due to both an increase and a decrease in demersal and pelagic biomass (Fig. 8b). The invertebrates/fish biomass ratio and TE showed an increase with time (Fig. 8c,h), significant for the former. The FIB index increased from 1975 to 1981 and then decreased till 2002, showing negative values after 1997. There was a non-significant increase in the secondary production index ( $L$ index) with time, both when production from 
primary producers and when both production from primary producers and detritus were considered in the analyses (Fig. 9). The probability that this ecosystem is fished sustainably was lower than $75 \%$ for the entire time period analysed, and it was lower than $50 \%$ for most of the analysis, when both production sources where included in the analysis (Fig. 9).

\section{Comparison with the south Catalan Sea}

Similarities on predicted trends of biomass were observed for several species both from the Catalan Sea (Coll et al. 2008a) and the Adriatic Sea (Table 4). Both models predicted a significant decline in demersal sharks through time. Norway lobster, hake, other
Norway lobster
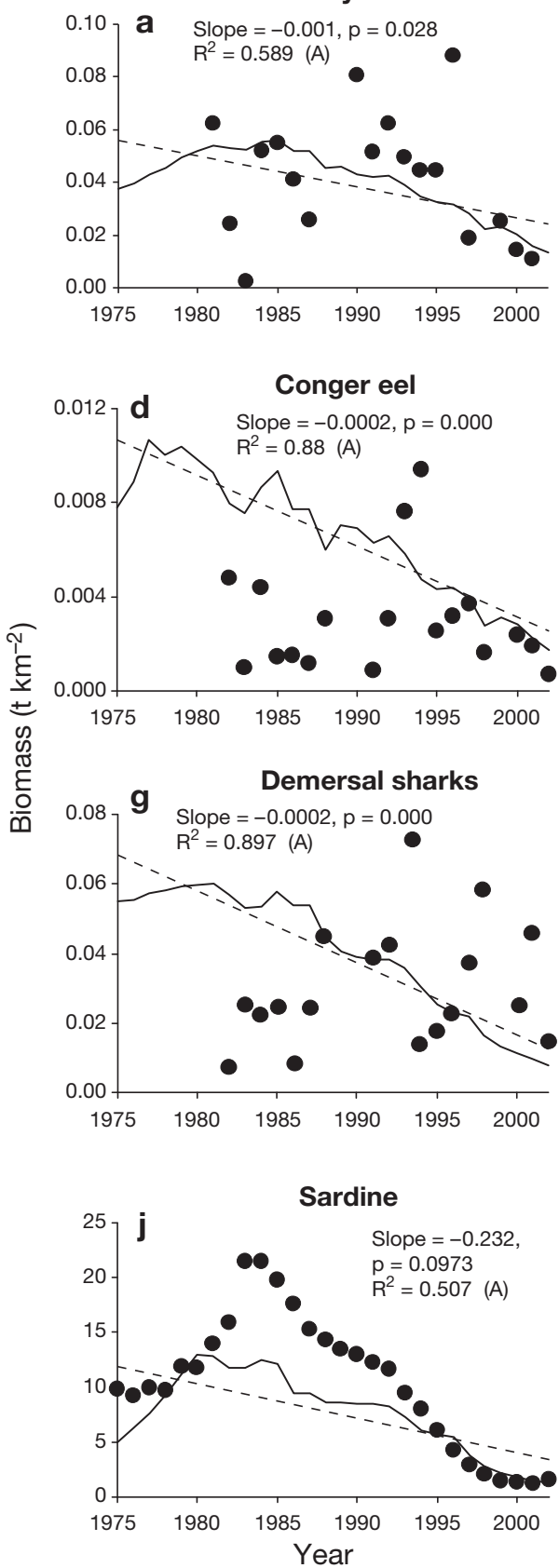

Hake (1)
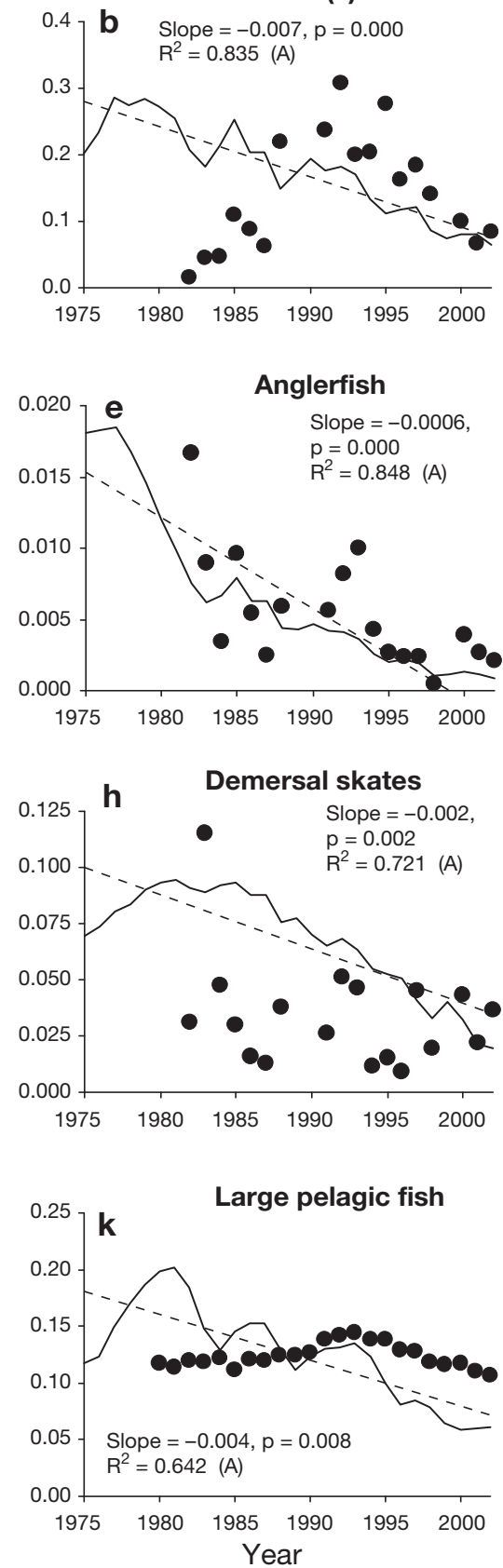

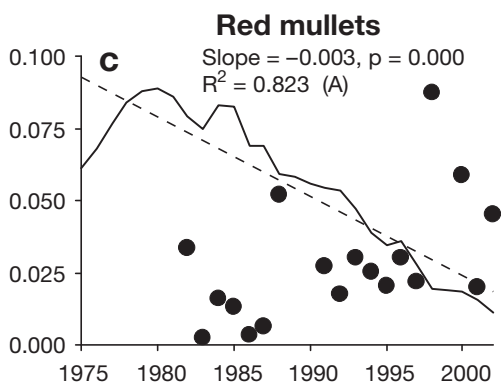

Flatfish

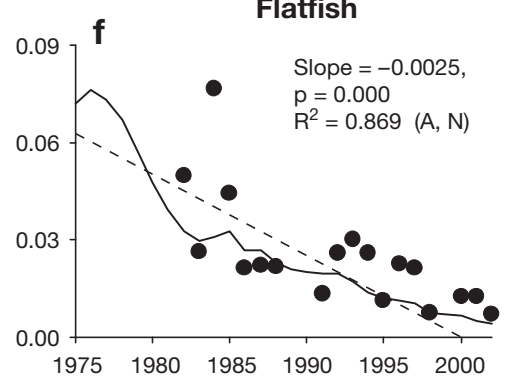

Anchovy

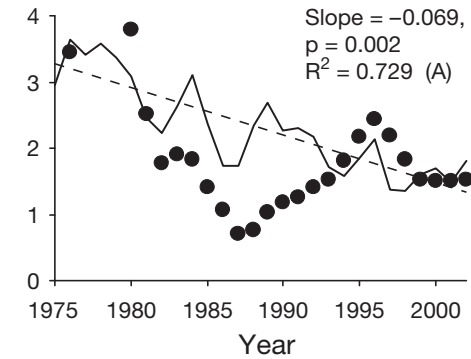

Fig. 4. Biomass trends $\left(\mathrm{t} \mathrm{km}^{-2}\right)$ for 11 species or groups of commercial fish (a-k) as estimated by Ecosim (solid lines) from the available data (dots) for the period 1975 to 2002. Relative biomass values are scaled from initial value of the baseline model. The estimated trends (dashed lines) are shown with the value of the slope, $\mathrm{p}$-value, and coefficient of variation $\left(\mathrm{R}^{2}\right)$ for the regression model. ' $\mathrm{A}$ ': data was corrected for autocorrelation and a generalized least squares model was applied for the regression. ' $N$ ': normality assumption violated. Hake (1): vulnerable hake group of fish $<40 \mathrm{~cm}$ in length mainly caught by trawling 

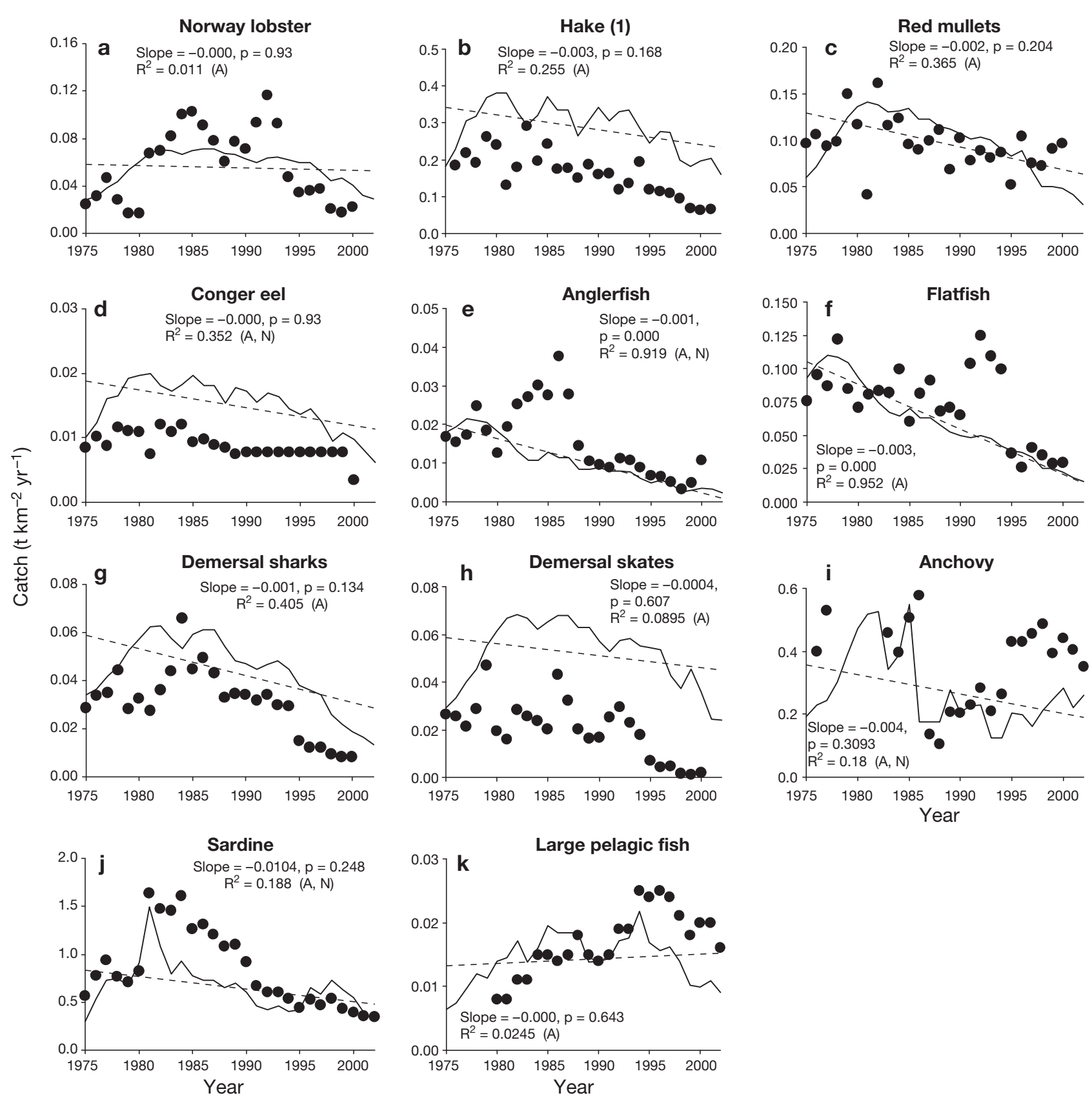

Fig. 5. Catch trends $\left(\mathrm{t} \mathrm{km}^{-2} \mathrm{yr}^{-1}\right)$ for 11 species or groups of commercial fish (a-k) as estimated by Ecosim (solid lines) and from available data (dots) for the period 1975 to 2002. The estimated trends (dashed lines) are shown with the value of the slope, $\mathrm{p}$-value, and coefficient of variation $\left(\mathrm{R}^{2}\right)$ for the regression model. ' $\mathrm{A}$ ': data was corrected for autocorrelation and a generalized least squares model was applied for the regression. ' $\mathrm{N}$ ': normality assumption violated

gadiformes, conger eel, anglerfish, anchovy, mackerel and large pelagic fish showed an overall decline with time as well. In both models, sardine biomass showed an increase followed by a decrease. Flatfish and loggerhead turtle biomass predictions differed in the 2 models. However, for several groups, namely jellyfish, suprabenthos, polychaetes, shrimps, crabs, cephalopods, other benthic invertebrates, red mullets, dem- ersal fish, benthopelagic fish, horse mackerel, Atlantic bonito, seabirds and dolphins, the results were similar in both the Catalan and the Adriatic Sea during the first half of the time series. All these groups showed an increase in biomass. During the second half of the time series, these groups showed a decline in Adriatic Sea biomass, while continuing to increase in the Catalan Sea. 


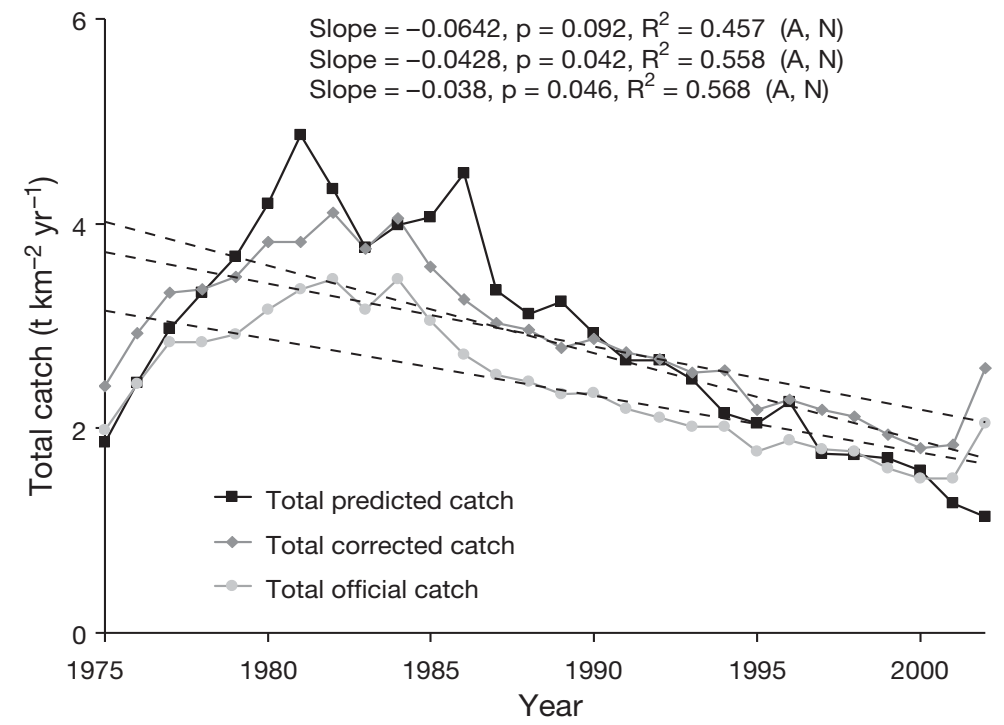

Fig. 6. Total catch data from the north-central (NC) Adriatic Sea as predicted from the ecosystem model (black) compared with official catch data (dark grey) and catch data corrected to account for discards and unregistered catch (light grey). The estimated trends are shown (dashed lines) with the value of the slope, p-value, and coefficient of variation $\left(\mathrm{R}^{2}\right)$ for the regression model (top: total predicted catch, middle: total corrected catch, bottom: total official catch). 'A': Data was corrected for autocorrelation and a generalized least squares model was applied for the regression. ' $\mathrm{N}$ ': normality assumption violated
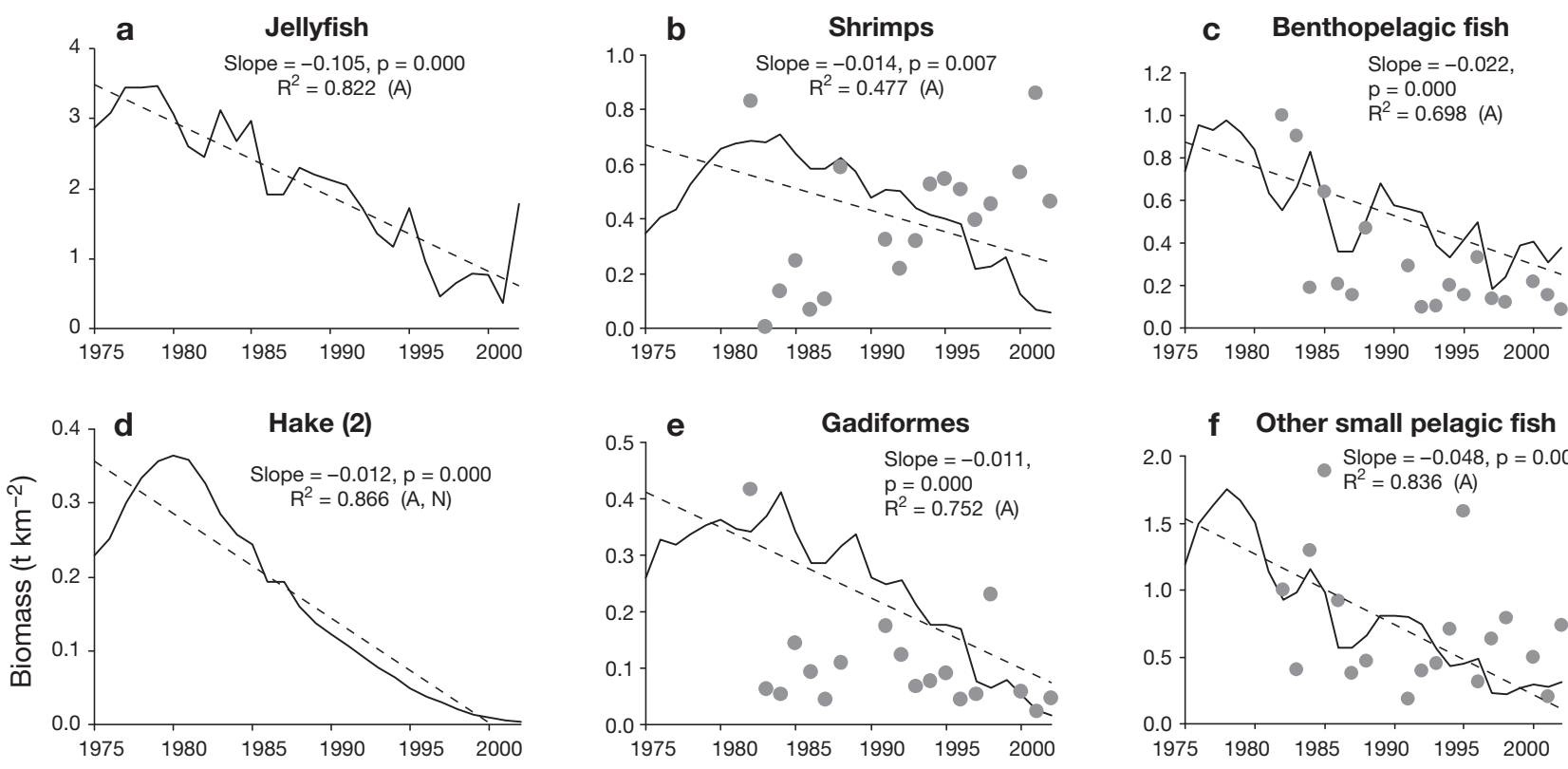

f Other small pelagic fish
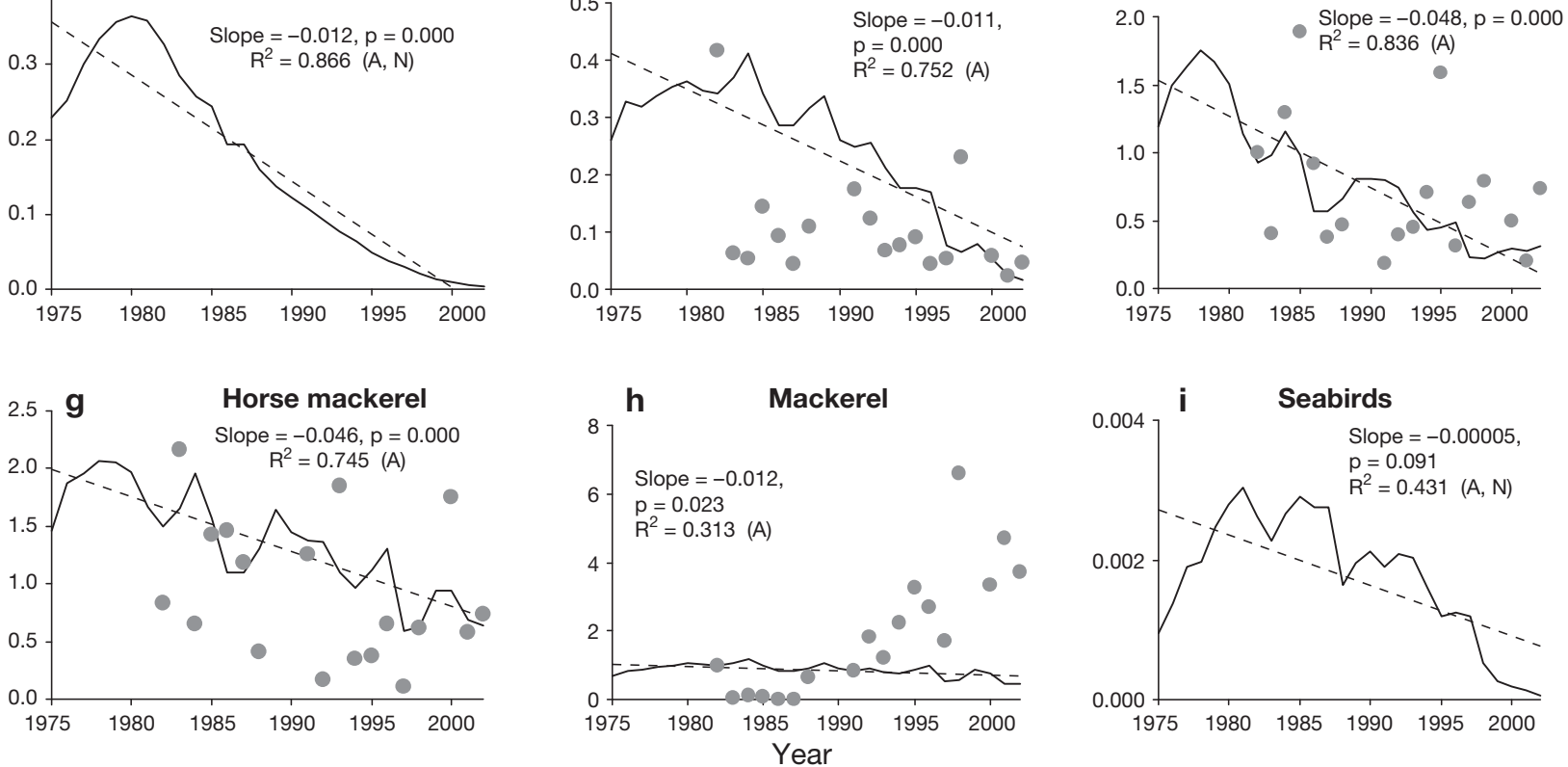

Fig. 7. Biomass trends $\left(\mathrm{t} \mathrm{km}^{-2}\right)$ for 9 species or groups (a-i) as estimated from the calibrated model for the period 1978 to 2003. Grey dots: data were not included in the calibration procedure as time series were not available for these species, or of poor quality. The estimated trends are shown (dashed lines) with the value of the slope, $p$-value, and coefficient of variation $\left(R^{2}\right)$ for the regression model. 'A': data was corrected for autocorrelation and a generalized least squares model applied for the regression. 

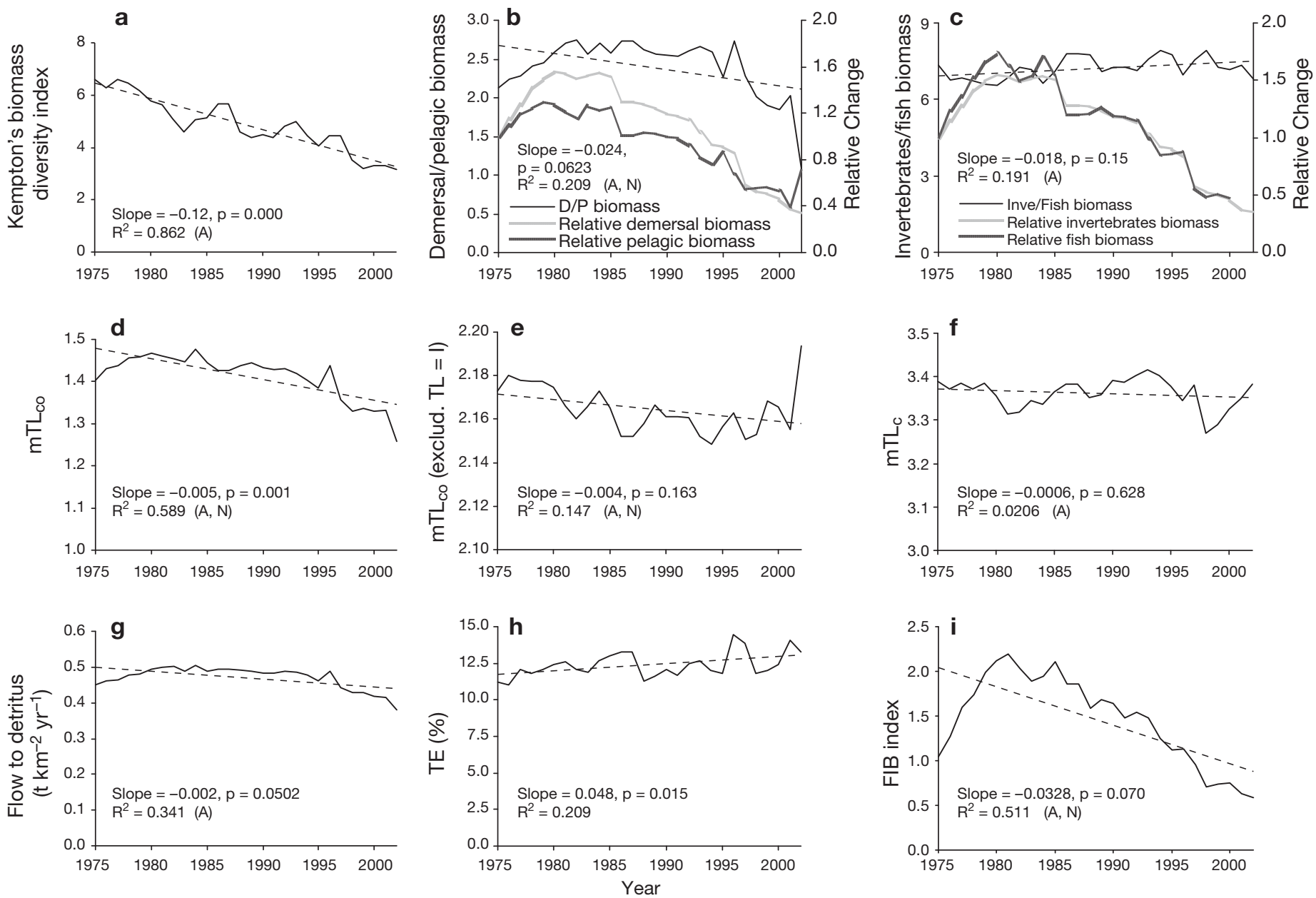

Fig. 8. Ecosystem indicators calculated from the calibrated model for the period 1975 to 2002. (a) Modified Kempton's index of biodiversity (biomass diversity index $Q^{\prime}$ ). (b) Demersal/pelagic biomass ratio, where relative demersal biomass and pelagic biomass are shown. (c) Invertebrates/fish biomass, where relative invertebrates and fish biomass are shown. (d) Mean trophic level of the community $\left(\mathrm{mTL}_{\mathrm{co}}\right)$. (e) Mean trophic level of the community $\left(\mathrm{mTL}_{\mathrm{co}}\right)$ excluding $\mathrm{TL}=1$. (f) Mean trophic level of the catch $\left(\mathrm{mTL}_{\mathrm{c}}\right)$. (g) Flow to detritus $\left(\mathrm{t} \mathrm{km}^{-2} \mathrm{yr}^{-1}\right)$. (h) Transfer Efficiency (TE\%). (i) FIB index. The estimated linear trends of the data are shown (dashed lines) with the value of the slope, $\mathrm{p}$-value, and coefficient of variation $\left(\mathrm{R}^{2}\right)$ for the regression model. 'A': data was corrected for autocorrelation and a gneralized least squares model applied for the regression. ' $\mathrm{N}$ ': normality assumption violated

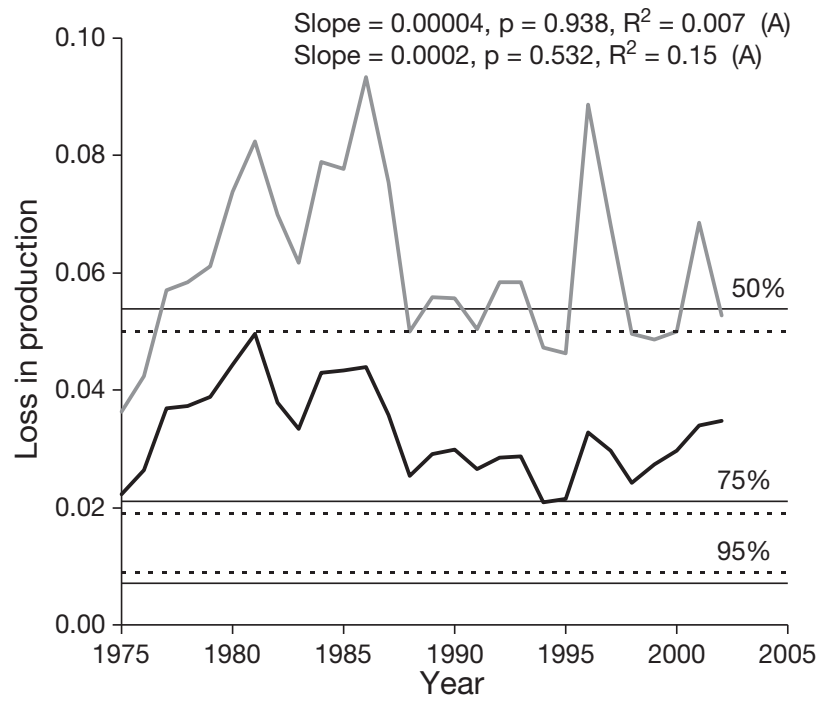

Fig. 9. Loss in Secondary Production Index $(L)$ considering (1) production from primary producers (black line) and (2) production from primary producers and detritus (grey line). Reference levels of $50 \%, 75 \%$ and $95 \%$ probability of the system being sustainable fished are indicated for (1) (dashed lines) and (2) (full lines). The estimated regression model is shown with the value of the slope, $p$-value, and coefficient of variation $\left(\mathrm{R}^{2}\right)$ (first production from primary producers). 'A': data was corrected for autocorrelation and a generalized least squares model applied for the regression 
Table 4. Comparison of predicted biomass trend and significance by functional group resulting from the fitting process of the north-central (NC) Adriatic model (present study) and the south Catalan Sea model (Coll et al. 2008a). i: increase, d: decrease, u: unclear pattern, $x$ : fitted to time series, (-): not fitted, na: not similar group available for comparison. ${ }^{* *}$ : Significant trend with $\mathrm{p}<0.05$

\begin{tabular}{|c|c|c|c|c|}
\hline \multirow{2}{*}{ Functional groups } & \multicolumn{2}{|c|}{ NC Adriatic Sea } & \multicolumn{2}{|c|}{ S Catalan Sea } \\
\hline & Fitting & Trend & Fitting & Trend \\
\hline Phytoplankton & & $\mathrm{id}^{* *}$ & & $\mathrm{u}$ \\
\hline Micro and mesozooplankton & & $\mathrm{u}$ & & $\mathrm{u}$ \\
\hline Macrozooplankton & & $\mathrm{u}$ & & $\mathrm{u}$ \\
\hline Jellyfish & & $\mathrm{id}^{* *}$ & & $\mathrm{i}$ \\
\hline Suprabenthos & & $\mathrm{id}^{* *}$ & & $\mathrm{i}$ \\
\hline Polychaetes & & id & & $\mathrm{i}$ \\
\hline Commercial bivalves and gastrop. & & id & na & na \\
\hline Benthic invertebrates & & $\mathrm{id}^{* *}$ & & $\mathrm{i}^{* *}$ \\
\hline Shrimps & & id & & $\mathrm{i}^{* *}$ \\
\hline Norway lobster & $\mathrm{x}$ & $\mathrm{id}^{* *}$ & & $\mathrm{~d}^{* *}$ \\
\hline Mantis shrimp & & $\mathrm{d}^{* *}$ & na & na \\
\hline Crabs & & id & & $\mathrm{i}^{* *}$ \\
\hline Benthic cephalopods & & $\mathrm{id}^{* *}$ & & $\mathrm{i}^{* *}$ \\
\hline Benthopelagic cephalopods & & id & & $\mathrm{i}^{* *}$ \\
\hline Hake (1) & $\mathrm{x}$ & $\mathrm{id}^{* *}$ & $\mathrm{x}$ & id \\
\hline Hake (2) & & $\mathrm{id}^{* *}$ & $\mathrm{x}$ & $\mathrm{d}^{* *}$ \\
\hline Other gadiformes & & $\mathrm{id}^{* *}$ & & $d^{* *}$ \\
\hline Red mullets & $\mathrm{x}$ & $\mathrm{id}^{* *}$ & $\mathrm{x}$ & $\mathrm{i}$ \\
\hline Conger eel & $\mathrm{x}$ & $\mathrm{id}^{* *}$ & $\mathrm{x}$ & id \\
\hline Anglerfish & $\mathrm{x}$ & $\mathrm{id}^{* *}$ & $\mathrm{x}$ & $\mathrm{d}^{* *}$ \\
\hline Flatfish & $\mathrm{x}$ & $\mathrm{d}^{* *}$ & $\mathrm{x}$ & $\mathrm{i}^{* *}$ \\
\hline Turbot and brill & & $\mathrm{d}^{* *}$ & na & na \\
\hline Demersal sharks & $\mathrm{x}$ & $\mathrm{d}^{* *}$ & $\mathrm{x}$ & $\mathrm{d}^{* *}$ \\
\hline Demersal skates & $\mathrm{x}$ & $\mathrm{id}^{* *}$ & na & na \\
\hline Demersal fish (1) & & $\mathrm{id}^{* *}$ & & $\mathrm{u}$ \\
\hline Demersal fish (2) & & id & & $\mathrm{i}^{* *}$ \\
\hline Bentopelagic fish & & id & & $\mathrm{i}^{* *}$ \\
\hline Anchovy & $\mathrm{x}$ & $\mathrm{id}^{* *}$ & $\mathrm{x}$ & id \\
\hline Sardine & $\mathrm{x}$ & id & $\mathrm{x}$ & id \\
\hline Other small pelagic fish & & $\mathrm{id}^{* *}$ & & $\mathrm{u}$ \\
\hline Horse mackerel & & $\mathrm{id}^{* *}$ & $\mathrm{x}$ & i \\
\hline Mackerel & & $\mathrm{id}^{* *}$ & $\mathrm{x}$ & $d^{* *}$ \\
\hline Atlantic bonito & & id & & $\mathrm{i}$ \\
\hline Large pelagic fish & $\mathrm{x}$ & $\mathrm{id}^{* *}$ & $\mathrm{x}$ & id \\
\hline Dolphins & & id & & $\mathrm{i}$ \\
\hline Loggerhead turtle & & $\mathrm{d}^{* *}$ & & i \\
\hline Sea birds & & $\operatorname{id}^{* *}$ & $\mathrm{x}$ & $\mathrm{i}^{* *}$ \\
\hline
\end{tabular}

Table 5. Comparison of predicted ecosystem indicators trend and significance by functional group that resulted from the fitting process of the north-central (NC) Adriatic model (present study) and the south Catalan Sea model (Coll et al. 2006, 2008a). i: increase, d: decrease, u: unclear pattern, ${ }^{* *}$ : significant trend with $\mathrm{p}<0.05$

\begin{tabular}{|c|c|c|c|c|}
\hline \multirow[t]{2}{*}{ Indicators } & \multicolumn{2}{|c|}{ NC Adriatic Sea } & \multicolumn{2}{|c|}{ South Catalan Sea } \\
\hline & Trend & Sig. & Trend & Sig. \\
\hline Demersal/pelagic biomass & $\mathrm{d}$ & & $\mathrm{i}$ & *** \\
\hline Invertebrates/fish biomass & $\mathrm{i}$ & & $\mathrm{i}$ & ** \\
\hline$Q^{\prime}$ biomass diversity index & $\mathrm{d}$ & *** & d & ** \\
\hline $\mathrm{TL}_{c o}$ (all TL) & $\mathrm{d}$ & ** & $\mathrm{i}$ & ** \\
\hline $\mathrm{TL}_{\mathrm{co}}(\mathrm{TL} \geq \mathrm{II})$ & id & & $\mathrm{d}$ & ** \\
\hline $\mathrm{TL}_{\mathrm{c}}$ & id & & id & \\
\hline$L$ index & $\mathrm{i}$ & & $\mathrm{i}$ & \\
\hline Total flow to detritus & id & & $\mathrm{i}$ & \\
\hline Transfer efficiency & $\mathrm{i}$ & *** & $\mathrm{i}$ & ** \\
\hline FIB index & id & & $\mathrm{u}$ & \\
\hline Total catch & id & & id & \\
\hline Discards & id & ** & $\mathrm{i}$ & ** \\
\hline
\end{tabular}

We found similar results in both ecosystems for the invertebrates/fish biomass ratio, the transfer efficiency, and the $L$ index, all of which increased through time (Table 5). The biomass diversity index $Q^{\prime}$ and the $\mathrm{mTL}_{\mathrm{co}}$ (excluding TL $=\mathrm{I}$ ) were predicted to decrease in both Mediterranean regions, although the latter index showed an increase during the beginning of the time series in the Adriatic Sea. The $\mathrm{mTL}_{\mathrm{c}}$ and total catch showed an increase followed by a decrease with time in both cases. Contradictory results were described for $\mathrm{mTL}_{\mathrm{co}}$ (including all TLs) and the $D / P$ biomass ratio, which showed a decline with time in the Adriatic Sea, and an increase in the Catalan Sea. The total flow of detritus and discards were predicted to increase in both the Adriatic and the Catalan Seas during the first half of the analysis period, but they decreased in the Adriatic Sea. The FIB index showed a clear increase followed by a pronounced decrease in the Adriatic Sea, while in the Catalan Sea it showed large variations through time, as a function of the continuous expansion of fisheries and decreases in marine resources (Coll et al. 2006).

\section{DISCUSSION}

\section{Ecosystem drivers of the Adriatic Sea food web}

Our results showed that trophic interactions likely played a key role in the biomass patterns observed throughout NC Adriatic Sea, similar to the south Catalan Sea (Coll et al. 2008a). Benthic invertebrates and anchovy were key prey elements of the system, while small demersal fish, sardine and micro-mesozooplankton were important predators. Hence an important proportion of the trophic flow in this ecosystem is controlled by lower and intermediate trophic-positioned organisms.

Fishing was also an important driver of invertebrate and fish populations of the Adriatic Sea. Simulations showed that, similar to the Catalan Sea (Coll et al. 2008a), fishing effort has increased from the 1970s to the 1990s, and is likely to continue to increase through the 2000s, although nominal fishing effort showed a constant trend from 1996 to 2002. Here we assumed that HP was linearly correlated with catching power, which could 
be an underestimation. However, predicted catches from the model (Fig. 6) showed a good agreement with available data, validating our fishing effort series as a proxy.

Results also showed that environmental drivers acted as key elements in the dynamics of marine resources in the Adriatic Sea. These drivers contributed to explain higher variability of the data than in the Catalan Sea (Coll et al. 2008a), and in both sites, environment was crucial in explaining the dynamics of small pelagic fish such as sardine. However, unlike the northwestern case study where a clear trend was not found, the anomaly functions predicted for the Adriatic Sea showed first an increase and then a significantly negative decreasing trend. Although the magnitude of the projected trend may be exaggerated, the phytoplankton biomass time series predicted by the model was significantly correlated with short time series of chlorophyll-a mean annual values from SEAWIFS for 1997 to 2002 (Spearman's rank $r=0.821, p=0.023$ ), showing a decrease with time (slope $=-0.024, \mathrm{p}=0.015, \mathrm{R}^{2}=$ 0.546). These results contrast to predictions for the southern-central Adriatic, where an increasing trend for primary production with time was observed due to advection of Mediterranean waters (Marasović et al. 1995, 2005). The positive correlation observed between the environmental anomaly and MOI is consistent with results of a detailed study from the northwestern Mediterranean Sea where MOI was positively related to abundance of target demersal species (Massuti et al. 2008). The anomaly functions were negatively correlated with SST, which showed a progressive increase. These results are consistent with previous studies suggesting that water warming and changing inflow of highly saline Mediterranean water into the Adriatic Sea may greatly effect fish communities (Dulčić et al. 1999, Grbec et al. 2002, 2007, 2008).

Due to limited data, we did not include other parameters in the correlations, such as oxygen concentration, benthic anoxia and mucilage events, nutrient loading and eutrophication, or wind anomalies, that can be pertinent in explaining the environmental anomaly (Zore-Armanda et al. 1988, Barmawidjaja et al. 1995, Degobbis et al. 2000, Agostini \& Bakun 2002, Grbec et al. 2002, 2003, 2008, Sangiorgi \& Donders 2004). For example, the Adriatic Sea receives considerable enrichment from river and land runoffs. Sangiorgi \& Donders (2004) describe progressive eutrophication beginning in the 20th century in the north-western Adriatic Sea, where eutrophication reached a maximum level around 1978, and where eutrophication levels were still high during the early 1990s but then showed a decline. Our results are consistent with the eutrophication peak (Sargiorgi \& Don- ders 2004) that coincides with the predicted environmental anomaly peaks, as well as the pro- gressive decline with time (Sangiorgi \& Donders (2004). Barmawidjaja et al. (1995) analysed benthic foraminifera records in the northern Adriatic basin, and describe intense and prolonged anoxic events during the 1980s due to eutrophication, highlighting that the ecological health of this area was at risk. These results are in line with data presented by Justić (1987) and Degobbis et al. (2000). Interestingly, a similar trend in catches (increase followed by a decrease) was described to occur in the Venice lagoon (Libralato et al. 2004) and has been related to changes in nutrient loading. In this lagoon, however, the effect of decreasing nutrient loading was observed 5 to 10 years earlier, from 1970 to 1980.

The correlation between an increase in SST and a decrease in phytoplankton and nutrients may in reality indicate a decrease in water column mixing and an increase of thermocline periods and depth, so that nutrients from the bottom of the sea can not reach the surface. Moreover, a decline in river and land runoff may then affect the highly productive front area where nutrient-enriched and riverine-influenced waters meet the more saline Mediterranean surface waters in the western Adriatic Sea (Agostini \& Bakun 2002). Boero \& Bonsdorf (2007) describe the Adriatic ecological history evolving from normal benthic and pelagic production with high fisheries production towards depleted production. This is attributed to several ecological phenomena including overfishing and jellyfish blooms during the 1980 s, which possibly changed the abundance of other species, followed by red tides, mucilage events and high microbial activity. The high vulnerability of the system to interactions at low and intermediate trophic-positioned organisms could be related with high fishing impact and the removal of higher trophic levels. That, in addition, can make the system more vulnerable to environmental factors. A combination of various environmental and anthropogenic factors, including fishing, increasing temperature and salinity, changes in eutrophication events and oceanographic patterns, is likely to explain the environmental anomaly functions revealed by our modelling. The detailed mechanisms involved need further examination.

\section{Changes in biomasses and catch}

Our results showed important biomass and trophic changes in the food web of the NC Adriatic Sea between 1975 and 2002, and our study revealed 2 distinct patterns: (1) commercially fished species such as anglerfish, hake, flatfish, Norway lobster, demersal 
sharks and skates, and anchovy decreased with time. (2) Biomass of other species increased between 1975 and 1980, then declined until 2002. This pattern was observed in low and intermediate trophic position organisms such as invertebrates, small and medium size demersal, and pelagic fish and seabirds.

The first pattern is related to the progressive exhaustion of demersal resources as a result of increasing fishing impact, as trawling efforts have increased over the last several decades (Fig. 2). This is consistent with other studies on marine resources in the Adriatic basin (Jukić-Peladić et al. 2001, Vrgoć et al. 2004, Bombace \& Grati 2007). Similar trends were described in the Catalan Sea (Coll et al. 2008a) for commercial species, with the exception of flatfish, which were predicted to increase in the north-western Mediterranean. In the Adriatic Sea, higher fishing rates are posed to flatfish due to beam trawling (Pranovi et al. 2001). Demersal sharks are non-target species, but showed marked declines due to by-catch of trawl fishing. This is consistent with studies from the northern and southern Catalan Sea, where decreasing catch and relative biomass trends were also recorded for demersal sharks from 1950 (Bas et al. 2003, Coll et al. 2008a), and from the Gulf of Lions, where bottom trawling has intensely impacted sharks from 1960 to 1990 (Aldebert 1997). The decline of marine turtles in the Adriatic Sea, unlike what was predicted in the Catalan Sea, may be related to high fishing mortality due to bottom trawling by-catch (Casale et al. 2004). Consumption of discards by marine turtles has been described to occur in the Western Mediterranean. It is less clear in other areas (Godley et al. 1997, Tomas et al. 2001), which may be due to limited data on stomach content in turtles.

The second pattern may be related to the indirect effects of fishing and eutrophication or other environmental factors. The removal of top predators from the Adriatic marine food web, along with increases in eutrophication may have produced an increase of prey biomass due to decreases in predatory mortality during the initial years of our time series and possibly before. This could explain the trends in small pelagic fish in the Adriatic Sea, such as the trends in sardine biomass from 1870 to 2000, where an increasing trend was described on landings during the early 1960s (Grbec et al. 2002). This was also the case in the south Catalan Sea where changes in biomass, mediated by the trophic web, were predicted to have direct and indirect impacts on the ecosystem (Pace et al. 1999), including the proliferation of non-commercial species at lower trophic levels (e.g. benthic invertebrates) or with higher turnover rates (e.g. cephalopods and benthopelagic fish) (Coll et al. 2008a). This is furthermore consistent with information from other areas of the
Mediterranean Sea (e.g. Pipitone et al. 2000, Daskalov et al. 2007). However, unlike the Catalan Sea, the Adriatic Sea showed a posterior decrease in biomass of intermediate trophic-positioned species. This decrease may be due to a progressive impoverishment of the ecosystem due to increasing fishing impacts (JukićPeladić et al. 2001, Bombace \& Grati 2007). Other contributing environmental factors have already been discussed and may include the negative effects of eutrophication on species with a near-bottom phase in their life cycles (Benović et al. 1987, De Leiva Moreno et al. 2000, Sangiorgi \& Donders 2004) as well as increasing temperature (Dulčić et al. 1999, Grbec et al. 2002, 2007, 2008). This ecological impoverishment has been observed both in the pelagic and demersal components.

\section{Ecosystem indicators and comparison}

Overall, ecosystem indicators showed ecological deterioration in the Adriatic Sea as a result of fishing impacts and bottom-up effects. An increase in fishing impacts was indicated by the decrease of the $\mathrm{mTL}_{\mathrm{co}}$ (excluding TL $=1$ ) and the modified version of Kempton's index of biodiversity. Furthermore, the loss of production due to fishing indicated a low probability that the ecosystem was being sustainably fished during the studied period. These results are in line with results from other Mediterranean areas and a global assessment for the Mediterranean Sea (Libralato et al. 2008, Coll et al. 2008b). The FIB index showed that catch increases at the beginning of the time series were not matched with higher production at lower trophic levels, but were due to previously described expansion of fisheries and bottom-up effects. However, this index fell below 0 between 1997 and 2002, possibly indicating the deterioration of the ecosystem (Christensen 2000).

Similarities with the Catalan Sea (lower $\mathrm{mTL}_{\mathrm{co}}$, lower biodiversity index, and higher $L$ index) indicated similar processes of increased fishing effort and impact with time (Coll et al. 2008a) during the first part of the time series. Differences between the 2 ecosystem regions are mainly related to decreases in biomass and production after the 1980s. This indicates that the Mediterranean is a heterogeneous ecosystem, and the fact that the Adriatic basin shows higher production and higher rates of eutrophication than the Catalan Sea, and lower rates of water exchange (Agostini \& Bakun 2002, Bosc et al. 2004) that other areas, may affect the dynamics of marine resources differently. Further ecosystem comparisons are expected to substantially contribute to this discussion. 


\section{Limitations of the analysis}

Our modelling was limited due to lack of data availability and data quality. Monitoring programs along the Mediterranean Sea are scarce, and data is fragmented, sometimes not standardized and very often not available to the broad scientific community. Our model was also limited as near shore waters were not included, but may be the refuge for prey species and early stages of predator juveniles. Further developments may overcome this problem. Our model-based discussion regarding environmental variables related to environmental function was also limited by the available time series data. Other environmental parameters may be important in explaining the results, including anoxia events, nutrients, as well as changes in patterns of salinity and water circulation. Due to data quality, catches were not included in the fitting procedure, but rather were used only to compare results. However, the model adequately predicted biomass and catches during the studied time period so these results indicated notable prediction capabilities of the calibrated model.

In this study we used a basic method for trend analysis correcting for autocorrelation. Our results suggested that most of the data was in fact autocorrelated, and only a few trends showed violations of the regression assumptions in terms of non-stationarity and nonlinearity. But more sophisticated trend analysis may show diverse species patterns.

\section{CONCLUSIONS}

In summary, our Ecosim trophodynamic processoriented model suggests that trophic interactions, fishing activity and environmental factors are essential elements in explaining changes in the NC Adriatic Sea food web during the last 3 decades. Crucial changes in the ecosystem included a change in the biomass of several commercial and non-commercial species. Two clear patterns emerged from our study. (1) There was a decrease of biomass with time, mainly observed in commercial species. This decrease was related to the progressive exhaustion of commercial resources due to increased fishing impacts. (2) First an increase and then a decreasing trend in biomass of low and intermediate trophic level organisms, as well as pelagic fish and seabirds, was observed. This pattern was related to indirect effects of fishing, eutrophication and climatic anomalies. Ecosystem indicators were consistent with ecosystem degradation over time in the Adriatic Sea, evidencing increasing fishing pressures and changing bottom-up effects and environmental factors. Similarities with the southern Catalan Sea showed that increasing fishing effort and increasing ecological impacts were linked through time. Differences between the 2 Mediterranean areas were mainly related to an overall decrease in biomass and production from 1980s to 2002 in the Adriatic Sea, which indicate the heterogeneity of the Mediterranean Sea.

Acknowledgements. This work was made possible by a bilateral co-operative-agreement between the Istituto di Scienze Marine (CNR), Italy, and the Consejo Superior de Investigaciones Científicas, Ciencia e Investigación (CSIC), Spain. The integrated project 'Site Effect Assessment Using Ambient Excitations' (SESAME) contract no. 036949-2, supported by the European Commission's Sixth Framework Programme, Sustainable Development, Global Change and Ecosystems, which allowed the continuation of this work, is greatly acknowledged. During part of the work, M.C. was supported financially by doctoral and postdoctoral fellowships from the Spanish Ministry of Science and Technology and the Ministry of Education and Science, and by Dalhousie University (Canada). The authors acknowledge all those colleagues who provided data and technical advice for the development of this work, in particular A. Artegiani, M. Azzali, N. Cingolani, G. Fabi, C. Froglia, M.E. Gramitto and E.B. Morello (Istituto di Scienze Marine-Sede di Ancona), A. Russo (Università Politecnica delle Marche), A. Di Natale (Aquastudio), S. Fonda Umani (Università di Trieste), D. Holcer (Natural History Museum of Zagreb), S. Libralato (Istituto Nazionale di Oceanografia e di Geofisica Sperimentale, Trieste), C. Piccinetti (Università di Bologna), R. Santolini (Università di Urbino), M. Zavatarelli (Università di Bologna) and B. Grbec (Institute of Oceanography and Fisheries of Split, Croatia). They also acknowledge V. Christensen (Fisheries Centre, University of British Columbia) for support on modelling and 4 anonymous reviewers for comments and suggestions.

\section{LITERATURE CITED}

Abella JA, Caddy JF, Serena F (1997) Do natural mortality and availability decline with age? An alternative paradigm for juvenile fisheries, illustrated by the hake Merluccius merluccius fishery in the Mediterranean. Aquat Living Resour 10:257-269

Affronte M, Scaravelli D (2001) Analysis of stranded sea turtles in the north-western Adriatic Sea. Zool Middle East 24:101-108

Agostini V, Bakun A (2002) 'Ocean triads' in the Mediterranean Sea: physical mechanisms potentially structuring reproductive habitat suitability (with example application to European anchovy, Engraulis encrasiclous). Fish Oceanogr 11:129-142

Ainsworth CH, Pitcher TJ (2006) Modifying Kempton's species diversity index for use with ecosystem simulation models. Ecol Indic 6:623-630

Aldebert Y (1997) Demersal resources of the Gulf of Lions (NW Mediterranean). Impact of exploitation on fish diversity. Vie Milieu 47:275-284

Allen R (1971) Relation between production and biomass. J Fish Res Board Can 28:1573-1581

> Araújo JN, Mackinson S, Standford RJ, Sims DW and others (2006) Modelling food web interactions, variation in plankton production and fisheries in the western English Channel ecosystem. Mar Ecol Prog Ser 309:175-187 
Arneri E (1981) Osservazioni sulle risorse demersali dell'Alto e Medio Adriatico. Tesi di Laurea, Università degli Studi di Bologna, Corso di Laurea in Scienze Biologiche. Mimeo.

Artegiani A, Bregant D, Paschini E, Pinardi N, Raicich F, Russo A (1997) The Adriatic Sea general circulation. Part I: air sea interactions and water mass structure. J Phys Oceanogr 27:1492-1514

Azzali M, De Felice A, Luna M, Cosimi G, Parmiggiani F (2002) The state of the Adriatic Sea centered on the small pelagic fish populations. PSZN I Mar Ecol 23(Suppl 1): 78-91.

Barmawidjaja DM, van der Zwaan GJ, Forissen FJ, Puskaric S (1995) 150 years of eutrophication in the northern Adriatic Sea: evidence from a benthic foraminiferal record. Mar Geol 122:367-384

Bas C, Maynou F, Sardà F, Lleonard J (2003) Variacions demogràfiques a les poblacions d'espècies demersals explotades: els darrers quaranta anys a Blanes i Barcelona. Arxius de la Seccions de Ciències, CXXXV. Secció de Ciències Biològiques. Institut d'Estudis Catalans, Barcelona

Bearzi G, Holcer D, Notarbartolo Di Sciara G (2004) The role of historical dolphin takes and habitat degradation in shaping the present status of northern Adriatic cetaceans. Aquat Conserv: Mar Freshw Ecosyst 14:363-379

Benović A, Dubravko J, Bender A (1987) Enigmatic changes in the hydromedusan fauna of the northern Adriatic Sea. Nature 326:597-600

Boero F, Bonsdorf E (2007) A conceptual framework for marine biodiversity and ecosystem functioning. PSZN I Mar Ecol 28(Suppl 1):134-145

Bombace G (1992) Fisheries of the Adriatic Sea. In: Colombo G, Ferrari I, Ceccherelli V U, Rossi R (eds) Marine Eutrophication and Population Dynamics. 25th European Marine Biology Symposium. Olsen \& Olsen, Fredensborg, p 379-389

Bombace G, Grati F (2007) Che succede alle risorse di pesca del Mediterraneo? Notiziario della Società Italiana di Biologia Marina 51:29-38

Bosc E, Bricau A, Antoine D (2004) Seasonal and interannual variability in algal biomass and primary production in the Mediterranean Sea, as derived from 4 years of SeaWiFS observations. Global Biogeochem. Cycles 18 GB1005 doi:10.1029/2003GB002034.

> Caddy JF, Abella AJ (1999) Reconstructioning reciprocal M vectors from length cohort analysis (LCA) of commercial size frequencies of hake, and fine mesh trawl surveys over the same grounds. Fish Res 41:169-175

Casale P, Laurent L, De Metrio G (2004) Incidental capture of marine turtles by the Italian trawl fishery in the north Adriatic Sea. Biol Conserv 119:287-295

Christensen V (2000) Indicators for marine ecosystems affected by fisheries. Mar Freshw Res 51:447-450

Christensen V, Walters C (2004) Ecopath with Ecosim: methods, capabilities and limitations. Ecol Modell 172:109-139

Christensen V, Walters C, Pauly D (2005) Ecopath with ecosim: a user's guide. Fisheries Centre of University of British Columbia, Vancouver

Cingolani N, Giannetti GG, Arneri E (1996) Anchovy fisheries in the Adriatic Sea. Sci Mar 60(suppl 2):269-277

Cingolani N, Kirkwood G, Arneri E, Santojanni A and others (2000) Discards from the Adriatic small pelagic fishery. Final report to the Commission of the European Communities, EU 97/065, IX + 439 pp

Cingolani N, Santojanni A, Arneri E, Belardinelli A, Giannetti G, Colella S, Donato F (2002a) Valutazione degli stocks pelagici di alici e sardine in Adriatico con metodi di dinamica di popolazione. Rapporto per il Ministero per le Politiche Agricole e Forestali, Rome

Cingolani N, Santojanni A, Arneri E, Belardinelli A, Giannetti G, Colella S Donato, FF (2002b) Stock assessment of sardine (Sardina pilchardus, Walb.) in the Adriatic Sea. Biologia Marina Mediterranea 9:82-88

Coll M, Shannon LJ, Moloney CL, Palomera I, Tudela S (2006) Comparing trophic flows and fishing impacts of a NW Mediterranean ecosystem with coastal upwellings by means of standardized ecological models and indicators. Ecol Model 198:53-70

Coll M, Santojanni A, Arneri E, Palomera I, Tudela S (2007) An ecosystem model of the northern and central Adriatic Sea: analysis of ecosystem structure and fishing impacts. J Mar Syst 67:119-154

Coll M, Libralato S, Tudela S, Palomera I, Pranovi F (2008a) Ecosystem overfishing in the ocean. PLoS One 3:e3881

Coll M, Palomera I, Tudela S, Dowd M (2008b) Food-web dynamics in the south Catalan Sea ecosystem (NW Mediterranean) for 1978-2003. Ecol Modell 217:95-116

Cury PM, Shannon LJ, Shin YJ (2003) The functioning of marine ecosystems: a fisheries perspective. In: Sinclair M, Valdimarsson G (eds) Responsible fisheries in the marine ecosystem. FAO and CABI Publishing, UK, p 103-123

> Cury PM, Shannon LJ, Roux JP, Daskalov GM, Jarre A, Moloney CL, Pauly D (2005) Trophodynamic indicators for an ecosystem approach to fisheries. ICES J Mar Sci 62: 430-442

> Daskalov GM, Grishin AN, Rodionov S, Mihneva V (2007) Trophic cascades triggered by overfishing reveal possible mechanisms of ecosystem regime shifts. Proc Natl Acad Sci USA 104:10518-10523

Degobbis, D, Precali R, Ivančić I, Smodlaka N, Fuks D, Kveder $S$ (2000) Long-term changes in the northern Adriatic ecosystem related to anthropogenic eutrophication. Int J Environ Pollut 13(1-6):495-533.

> De Leiva Moreno JI, Agostini VN, Caddy JF, Carocci F (2000) Is the pelagic-demersal ratio from fishery landings a useful proxy for nutrients availability? A preliminary data exploration for the semi-enclosed seas around Europe. ICES J Mar Sci 57:1091-1102

Dulčić J, Grbec B, Lipej L (1999) Information on the Adriatic ichthyofauna-effect of water warming? Acta Adriat 40: 33-43

> Godley BJ, Smith SM, Clark PF, Taylor JD (1997) Molluscan and crustacean items in the diet of the loggerhead turtle, Caretta caretta (Linnaeus, 1758) (Testudines: Chelonidae) in the eastern Mediterranean. J Molluscan Stud 63:474-476

Grbec B, Dulčić J, Morović M (2002) Long-term changes in landings of small pelagic fish in the eastern Adriatic - possible influence of climate oscillations over the Northern Hemisphere. Clim Res 20:241-252

Grbec B, Morović M, Zore-Armanda M (2003) Mediterranean Oscillation and its relationship to salinity fluctuation in the Adriatic Sea. Acta Adriat 44:61-76

Grbec B, Vilibić I, Bajić A, Morović M, Bec Paklar G, Matić F, Dadić V (2007) Response of the Adriatic Sea to the atmospheric anomaly in 2003. Ann Geophys 25:835-846

Grbec B, Morović M, Dulčić J, Marasović I, Ninčević Z (in press) Climate changes impact on the Adriatic Sea ecosystem. Fresenius Environ Bull 17:

Groombridge B (1990) Marine turtles in the Mediterranean: distribution, population status, conservation. Nature and environment No. 48. Council of Europe, Strasbourg

Guénette S, Heymans JJ, Christensen V, Trites AW (2006) Ecosystem models show combined effects of fishing, predation, competition, and ocean productivity on Steller sea 
lions (Eumetopias jubatus) in Alaska. Can J Fish Aquat Sci 63:2495-2517

Heymans J (2004) The effects of internal and external control on the northern Benguela ecosystem. In: Sumaila UR, Boyer D, Skogen MD, Steinshamn SI (eds) Namibia's fisheries. Ecological, economic and social aspects. Eburon Academic Publishers, Delft, p 29-52

International Commission for the Conservation of Atlantic Tunas (ICCAT) (2003) Report of the 2002 Atlantic Bluefin Tuna Stock Assessment Session SCRS/2002/012. Col Vol Sci Pap ICCAT 55:710-937

International Commission for the Conservation of Atlantic Tunas (ICCAT) (2004) Mediterranean Swordfish Stock Assessment Session SCRS/2003/015. Col Vol Sci Pap ICCAT 56(3):789-837

Jukić-Peladić S, Vrgoć N, Krstulović-Sifner S, Piccinetti C, Piccinetti-Manfrin G, Marano G, Ungaro N (2001) Longterm changes in demersal resources of the Adriatic Sea: comparison between trawl surveys carried out in 1948 and 1998. Fish Res 53:95-104

Justić D (1987) Long-term eutrophication of the northern Adriatic Sea. Mar Pollut Bull 18:281-284

Kempton RA, Taylor LR (1976) Models and statistics for species diversity. Nature 262:818-820

Lalli CM, Parsons TR (1993) Biological oceanography: an introduction. Pergamon Press, Oxford

> Libralato S, Pranovi F, Raicevich S, Da Ponte F, Giovanardi O, Pastres R, Torricelli P, Mainardi D (2004) Ecological stages of the Venice Lagoon analyzed using landing time series data. J Mar Syst 51:331-344

Libralato S, Coll M, Santojanni A, Solidoro C, Arneri E, Palomera I (2005) Comparison between trophic models of protected and fishing areas for an ecosystem approach to fisheries in Adriatic Sea. ICES CM 2005/BB:11

Libralato S, Coll M, Tudela S, Palomera I, Pranovi F (2008) A new index to quantify ecosystem impacts of fisheries as the removal of secondary production. Mar Ecol Prog Ser 355:107-129

Lindeman RL (1942) The trophic-dynamic aspect of ecology. Ecology 23:399-418

- Marasović I, Grbec B, Morović M (1995) Long-term production changes in the Adriatic. Neth J Sea Res 34:267-273

- Marasović I, Ninčević Z, Kuspilić G, Marinović S, Marinov S (2005) Long-term changes of basic biological and chemical parameters at two stations in the middle Adriatic. J Sea Res 54:3-14

Massutí E, Monserrat S, Oliver P, Moranta J and others (2008) The influence of oceanographic scenarios on the population dynamics of demersal resources in the western Mediterranean: hypothesis for hake and red shrimps off Balearic Islands. J Mar Syst 71:421-438

Mattei N, Pellizzato M (1996) A population study on three stocks of a commercial Adriatic pectinid (Pecten jacobaeus). Fish Res 26:49-65

Ott J (1992) The Adriatic benthos: problems and perspectives. In: Colombo G, Ferrari I, Ceccherelli VU, Rossi R (eds) Marine eutrophication and population dynamics. 25th European Marine Biology Symposium. Olsen \& Olsen, Fredensborg, p 367-378.

Pace LP, Cole JJ, Carpenter SR, Kitchell JF (1999) Trophic cascades revealed in diverse ecosystems. Trends Ecol Evol $14: 483-488$

Papacostantinou C, Farrugio H (2000) Fisheries in the Mediterranean. Mediterr Mar Sci 1:5-18

Pauly D, Christensen V (1995) Primary production required to sustain global fisheries. Nature 374:255-257

Pauly D, Christensen V, Dalsgaard J, Froese R, Torres FJ
(1998) Fishing down marine food webs. Science 279: 860-863

Piccinetti C, Piccinetti Manfrin G (1984) Distribuzione di Pelagia noctiluca in Adriatico dal 1976 al 1983. Nova Thalassia 6(Suppl):51-68

Pinardi N, Zavatarelli M, Arneri E, Crise A, Ravaioli M (2006) The physical, sedimentary and ecological structure and variability of shelf areas in the Mediterranean sea (27). In: Robinson AR, Brink KH (eds) The sea, Vol. 14, Harvard University Press, Cambridge, p 1245-1331

> Pipitone C, Badalamenti F, D'Anna G, Patti B (2000) Fish biomass increase alter a 4 -year trawl ban in the Gula of Castellamare (NW Sicily, Mediterranean Sea). Fish Res 48:23-30

Piroddi C 2008. An ecosystem-based approach to study two dolphin populations around the Island of Kalamos, Ionian Sea, Greece. MSc thesis, University of British Columbia, Vancouver

Plagányi ÉE 2007. Models for an ecosystem approach to fisheries. FAO Fisheries Technical Paper. No. 477. FAO, Rome

> Pranovi F, Raicevich S, Franceschini G, Torricelli P, Giovanardi O (2001) Discard analysis and damage to non-target species in the rapid trawl fishery. Mar Biol 139:863-875

Regner S (1996) Effects of environmental changes on early stages and reproduction of anchova in the Adriatic Sea. Sci Mar 60(Suppl 2):167-177

Revelante N, Gilmartin M (1977) The effects of the northern Italian rivers and eastern Mediterranean ingressions on the phytoplankton of the Adriatic Sea. Hydrobiologia 56: $229-240$

Riedl R (1986) Fauna y flora del Mar Mediterráneo. Omega, Barcelona

Rochet MJ, Trenkel VM (2003) Which community indicators can measure the impact of fishing? A review and proposals. Can J Fish Aquat Sci 60:86-99

Sangiorgi F, Donders TH (2004) Reconstructing 150 years of eutrophication in the north-western Adriatic Sea (Italy) using dinoflagellate cysts, pollen and spores. Estuar Coast Shelf Sci 60:69-79

Santojanni A, Arneri E, Barry C, Belardinelli A, Cingolani N, Giannetti G, Kirkwood G (2003) Trends of anchovy (Engraulis encrasicolus, L.) biomass in the northern and central Adriatic Sea. Sci Mar 67:327-340

Santojanni A, Cingolani N, Arneri E, Kirkwood G and others (2005) Stock assessment of sardine (Sardina pilchardus, Walb.) in the Adriatic Sea, with an estimate of discards. Sci Mar 69:603-617

Santojanni A, Arneri E, Bernardini V, Cingolani N, Di Marco M, Russo A (2006a) Effects of environmental variables on recruitment of anchovy in the Adriatic Sea. Clim Res 31: 181-193

Santojanni A, Cingolani N, Arneri E, Belardinelli A and others (2006b) Recruitment of sardine (Sardina pilchardus Walbaum, 1792) in the Adriatic Sea and environmental factors. Biol Mar Mediterr 13:158-166

Scaccini A (1965) Biologia e pesca dei tonni nei mari italiani. Ministero Mar Mercant Mem 12

Shannon LJ, Christensen V, Walters C (2004) Modelling stock dynamics in the southern Benguela ecosystem for the period 1978-2002. Afr J Mar Sci 26:179-196

Shannon LJ, Coll M, Neira S, Cury PM, Roux JP (•••) The role of small pelagic fish in the ecosystem. In: Checkley DM, Roy, C, Alheit J, Oozeki Y (eds) Clim Change Small Pelagic Fish (in press)

Šimunović A (1997) Quantitative and qualitative investigations of benthic communities in the areas of mobile bottoms of the Adriatic Sea. Acta Adriat 38:77-194 
Smith TM, Reynolds RW (2004) Improved Extended Reconstruction of SST (1854-1997). J Clim 17:2466-2477

Tomas J, Aznar FJ, Raga JA (2001) Feeding ecology of the loggerhead turtle Caretta caretta in the western Mediterranean. J Zool 255:525-532

Tudela S (2004) Ecosystem effects of fishing in the Mediterranean: an analysis of the major threats of fishing gear and practices to biodiversity and marine habitats. General fisheries commission for the Mediterranean studies and reviews 74. Food and Agriculture Organization of the United Nations, Rome

Vrgoć N, Arneri E, Jukić-Peladić S, Krstulović Šifner S and others (2004) Review of current knowledge on shared demersal stocks of the Adriatic Sea. GCP/RER/010/ITA/ TD-12. AdriaMed Technical Documents, 12, Termdi

Walsh JJ (1981) A carbon budget for overfishing off Peru. Nature 290:300-304

Walters CJ, Juanes F (1993) Recruitment limitation as a consequence of natural selection for use of restricted feeding habitats and predation risk taking by juvenile fishes. Can J Fish Aquat Sci 50:2058-2070

Editorial responsibility: Konstantinos Stergiou, Thessaloniki, Greece
Walters C, Christensen V, Pauly D (1997) Structuring dynamic models of exploited ecosystems from trophic mass-balance assessments. Rev Fish Biol Fish 7:139-172

Wieczorek SK, Campagnuolo S, Moore PG, Froglia C, Atkinson RJA, Gramitto ME, Bailey N (1999) The composition and fate of discards from the Nephrops norvegicus trawling in Scottish and Italian waters. Final report on European Community funded project, 96/092, Ancona

Zavatarelli M, Raicich F, Bregant D, Russo A, Artegiani A (1998) Climatological biogeochemical characteristics of the Adriatic Sea. J Mar Syst 18:227-263

Zore-Armanda M, Stojanoski L, Vukadin I (1988) Time series of oceanographic parameters: Eutrophication of the open Adriatic Sea. FAO Fish Rep 394:71-77

Zotier R, Bretagnolle V, Thibault JC (1999) Biogeography of the marine birds of a confined sea, the Mediterranean. J Biogeogr 26:297-313

Županović S, Jardas I (1989) Fauna i flora Jadrana: Jabucka Kotlina. Institut za Oceanografiju i Ribarstvo. Vol IV. Logos, Split

Submitted: August 19, 2008; Accepted: January 26, 2009

Proofs received from author(s): April 7, 2009 